UNIVERSIDADE DE SÃO PAULO

PROGRAMA DE PÓS-GRADUAÇÃO EM INTEGRAÇÃO DA AMÉRICA LATINA

Nico Rodrigues

O CINEMA ESTÉTICO-IDEOLÓGICO DA UNIDAD POPULAR NO CONTEXTO DO NUEVO CINE LATINOAMERICANO 
Nico Rodrigues

(Antônio G. F. Rodrigues)

\section{O CINEMA ESTÉTICO-IDEOLÓGICO DA UNIDAD POPULAR NO CONTEXTO DO NUEVO CINE LATINOAMERICANO}

Dissertação apresentada ao Programa de PósGraduação em Integração da América Latina da Universidade de São Paulo, como requisito parcial para a obtenção do título de Mestre em Integração da América Latina.

Orientador: Prof. Dr. Afrânio Mendes Catani 
Data da Defesa:

Banca Examinadora

Prof. Dr Instituição:

Julgamento:

Assinatura:

Prof. Dr. Instituição:

Julgamento:

Assinatura:

Prof. Dr. Instituição:

Julgamento:

Assinatura: 
"Creo en el cine popular y creo en la literatura popular, entendiendo como popular la necesidad de que estén dirigidos al pueblo" (Littin)

"Un País sin cine documental es como una familia sin álbum de fotografías" (Guzmán )

"A cultura cinematográfica brasileira é precária e marginal" (Glauber) 
Ao Amor,

Livre, pleno e ilimitado. 


\section{Agradecimentos}

À Capes pela bolsa concedida e sem a qual este trabalho teria sido muito mais árduo.

Aos professores Dr. Afrânio Catani e Dr. Atílio Avancini pela confiança e apoio. Aos professores Dr. Henri Arraes Gervaiseau, Dra. Lucia Bruno, Dra. Marília Franco e Dr. Maurício Reinaldo Gonçalves pelo apoio e incentivo.

Aos Amigos Vanderlei Mastropaulo, Rodrigo Machado, Flávio Moura e Carol Kastanheda pela Amizade sincera.

Às minhas irmãs Amélia, Dóra, Táta, Jô e Rita pela confiança e paciência. Às Amigas Neuli Tenório, Tatiana da Sorte, Luciana Porto, Marisa Oliveira e Branca pelo Carinho.

À Raquel Carvalho e ao Willian Almeida pelo apoio imprescindivel.

À Rosa Montero, Companheira, Amiga, pela compreensão, Carinho e apoio.

À professora Dra. Josette Monzani, Amiga, Orientadora, Conselheira, Fundamental! 


\section{$\underline{\text { Sumário }}$}

RESUMO

RESUMEN

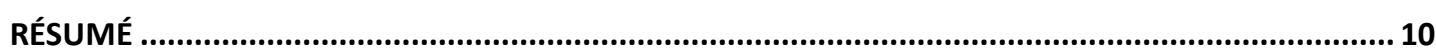

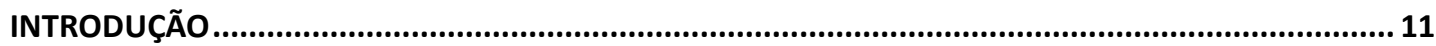

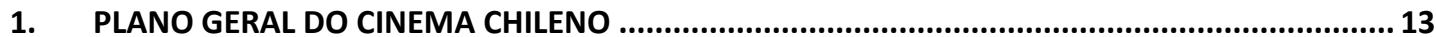

2. REALISMO E IMAGEM DOCUMENTAL: O MOMENTO DECISIVO …............................................ 18

3. FABULAÇÃO E TOMADA DE POSIÇÃO: CINÉMA VÉRITÉ ........................................................... 21

4. PICARDIA E ANTROPOFAGIA NO CONE SUL: O NUEVO CINE LATINOAMERICANO ................... 31

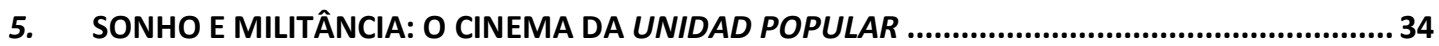

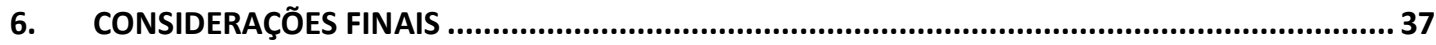

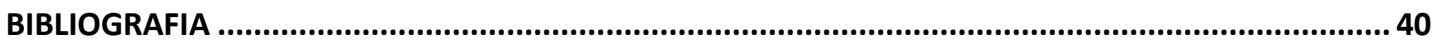

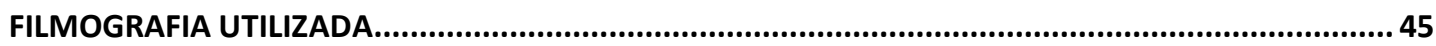

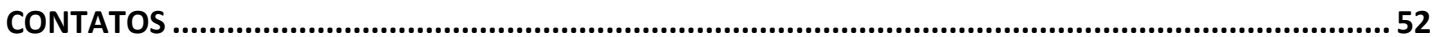

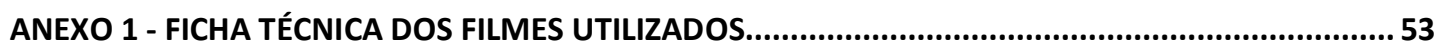

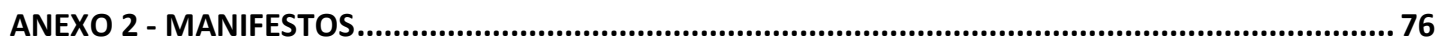




\section{RESUMO}

RODRIGUES, Nico. O cinema estético-ideológico da Unidad Popular no contexto do Nuevo Cine Latinoamericano. Dissertação de Mestrado Programa de Pós-Graduação em Integração da América Latina, Universidade de São Paulo, 2010. 120 p.

Este trabalho se propõe investigar o desenvolvimento cinematográfico ocorrido durante o período da Unidad Popular e quais os principais elementos ideológicos e estéticos que resultou no processo criativo desse Cinema específico, a fim de tentar estabelecer os diálogos possíveis entre ele e o Nuevo Cine Latinoamericano, que o contém: as influências formais e o momento histórico, o ambiente político em que se deu origem e o seu entorno, procurando estabelecer as relações entre a atividade cinematográfica e o momento cultural, político e social que vivem nesta época, principalmente, Chile e Brasil.

Palavras-chave: Cinema, América Latina, História, Chile, Brasil, Nuevo Cine, Cinema Novo, Documentário, Política, Golpe de Estado, Regime militar 


\section{RESUMEN}

RODRIGUES, Nico. El cine estético-ideológico de la Unidad Popular en el contexto del Nuevo Cine Latinoamericano. Disertación Máster Programa de Pós-Grado en Integração da América Latina, Universidade de São Paulo, 2010. 120 p.

Este trabajo tiene como objetivo investigar el desarrollo cinematográfico ocurrido durante la Unidad Popular y cuales son los principales elementos ideológicos y estéticos que resultaron en el proceso creativo de este Cine específicamente, para tratar de establecer posibles diálogos entre él y el Nuevo Cine Latinoamericano: las influencias formales y el momento histórico, el ambiente político en que se dio origen y su alrededor, buscando establecer las relaciones entre: la actividad cinematográfica y el momento cultural, político y social que viven, principalmente en esta época, Chile y Brasil.

Palabras clave: Cine, América Latina, História, Chile, Brasil, Nuevo Cine, Cinema Novo, Documental, Política, Golpe de Estado, Regimen militar 


\section{RÉSUMÉ}

RODRIGUES, Nico. Le Cinéma esthétique et idéologique de l'Unité Populaire dans le contexte du Nuevo Cine Latinoamericano. Dissertação de Mestrado - Programa de Pós-Graduação em Integração da América Latina, Universidade de São Paulo, 2010. 120 p.

Cet travail propose d'étudier le développement du film s'est produite lors de l'Unité Populaire et les principaux éléments idéologiques et esthétiques qui ont abouti au processus de création de ce Cinéma, pour essayer d'établir des dialogues possibles entre lui et le Nuevo Cine Latinoamericano, qui le contient: l'influences formelles et le moment historiques, l'environnement politique dans lequel il a pris naissance et ses environs, en essayant d'établir la relation entre l'activité cinematographique et le temps culturel du cinéma, de vie politique et sociale de cette époque, en particulier le Chili et le Brésil.

Mots-clés: Cinéma, Amérique Latine, Histoire, Chili, Brésil, Nuovo Cine, Cinéma Nouvelle, Documentaire, Politique, Coup d'Etat, le régime militaire 


\section{Introdução}

Chile e Brasil, décadas de 60 e 70. A circulação de cineastas e críticos brasileiros no país irmão, tanto em festivais quanto em exílio, durante este período de efervescência cinematográfica, é bastante conhecido. Os rumos políticos e históricos dos dois países correm em paralelo, no Brasil com alguns anos de antecedência. $\mathrm{O}$ cinema militante, politicamente engajado, é a arma de jovens idealistas e instrumento de conscientização das massas quanto ao seu "papel histórico". Mas, se no Brasil "o povo estava mais na tela do que na sala de exibição", como bem observa nosso ilustre teórico Paulo Emílio, no Chile, onde estava o povo? A relação entre ideologia e estética, o que aproxima e o que distancia o público (destinatário final de todo filme) nesses cinemas. Esta é uma das preocupações do presente trabalho.

Assim, a construção do pensamento ideológico e estético dos cineastas da Unidad Popular e, de forma mais geral, latinoamericanos, considerando-se seus respectivos primeiros filmes, está na base da análise aqui pretendida sobre o diálogo possível de se estabelecer entre esses diretores.

A crença na capacidade revolucionária popular e a frustração com os golpes militares, no Chile; a relação destes cineastas com o Estado, antes e após o golpe, a Unidad Popular chilena e os Cinemas de esquerda na América Latina, são temas abordados nesta pesquisa, a qual procura os pontos comuns e as divergências entre esses cinemas e as possíveis influências existentes entre esses diretores.

O interesse por esse cinema específico, o Nuevo Cine Latinoamericano e, sobretudo, o Cinema militante da Unidad Popular, se faz presente em um momento de reflexão acerca das possibilidades do fazer cinema em um continente que experimenta numa recente "democracia", a ampliação de suas produções em um contexto de transformação, no qual começa a se projetar um novo ambiente político e social. 
Assim, temos por objetivos:

Pensar um Cinema que seja, ao mesmo tempo, militante e criativo, inovador em sua forma; que seja capaz de procurar novos caminhos, aprendendo com os já trilhados, sempre na perspectiva de um Cinema genuinamente latino-americano, atual e consciente.

Tentar levantar, para oferecer uma contribuição à historiografia do Cinema latino-americano nos anos de 60 e 70, proximidades possíveis e dessemelhanças importantes presentes nessa cinematografia, não somente no que diz respeito à ideologia dela norteadora, mas também no seu modo criativo, na sua forma representacional.

Buscar caracterizar um possível ponto de origem entre esses cinemas, de uma cinematografia do 'vir a ser', é nosso principal propósito. 


\section{Plano Geral do Cinema Chileno}

“(...) una actividad absorbente que atrajo (...) una emigración quijotesca de artistas y técnicos desplazados del mundo viejo, por cuestiones politicas o religiosas o graves discrepancias del concepto artístico."

(SANTANA, 1957, pg. 13)

Os primeiros anos do Cinema chileno nos parece ser, assim como em quase toda a América Latina, marcado pela precariedade e falta de incentivos.

A partir dos dados existentes atualmente, o início da atividade cinematográfica no país andino data por volta de 1900 com os primeiros experimentos realizados em solo chileno, como um exercício rotineiro de bombeiros em 1902 e exibição de películas curtas trazidas sobretudo da Europa e dos Estados Unidos. No ano do centenário da independência (1910), segundo Alberto Santana (1957), pesquisador e cineasta, chegou ao Chile certo "don" Julio Chenevey da França, o qual teria montado em seu estabelecimento um laboratório para revelação e cópia de películas especialmente para processar as fitas que seriam impressas nos festejos das comemorações do centenário da independência. Teriam sido cinco meses de trabalho até o laboratório ficar pronto para receber os filmes a serem revelados. Porém, um mês antes dos festejos, acontece o azar de morrer o presidente da república numa viagem à Alemanha, onde tinha ido se tratar. Como já não havia clima para festas, Chenevey teria usado os rolos de filme que estavam reservados para a festa para filmar a chegada dos restos mortais do então ex-presidente. As películas que eram para a festa e passaram a ser do funeral deram origem ao primeiro filme chileno feito com estrutura de "grande produção": Los funerales del Presidente Pedro Montt. Outro autor, Carlos Ossa, professor da Universidad de Chile, atribui a autoria do filme a Arturo Larrain Lecaros. 
Independente de quem foi o autor do filme, o fato é que o excelentíssimo senhor expresidente da república estragou a festa, e o que é pior, alterou substancialmente o roteiro do primeiro filme do Cinema chileno e que marca, de certa forma, o início da produção de filmes mais bem estruturados narrativamente. Neste mesmo ano, Adolfo Urzua Rozas realiza o primeiro longa metragem de ficção chileno: Manuel Rodriguez. Entre 1915 e 1921, o italiano Salvador Giambastiani, após alguns trabalhos na Argentina, constrói um pequeno estúdio em Santiago e forma sua equipe, produzindo alguns filmes argumentais e documentários, como Santiago antiguo (1915), Fiesta de los estudiantes (1916) e Recuerdos del mineral El Teniente (1919).

Os anos seguintes foram marcados por pequenos filmes de atualidades, algo comum no mundo inteiro, e algumas paródias de filmes estrangeiros, além de anedotas, que não refletia a identidade da sociedade chilena como um todo.

Carlos Ossa, em sua História del cine chileno, é bastante crítico até com os poucos filmes produzidos até a década de 1920. Ele destaca Grito en el mar (1924) de Pedro Sienna, pelo rigor técnico e interpretativo e Las chicas de la Avenida Pedro Montt (1925) de Alberto Santana. Cita também o caso do suicídio do líder popular Luis Emilio Recabarren, que será lembrado depois no Manifesto dos Cineastas da Unidad Popular, ocorrido em 19 de dezembro de 1924, e filmado por Carlos Pellegrini e Luis Pizarro, e que, assim como quase todo material dessa época, se perdeu. Ainda de 1924, cita Juro no volver a amar, filme de estréia de Jorge Délano, mas não por questões técnicas ou estéticas, mas pelo fato de a câmera ter sido fabricada pelo próprio fotógrafo, Luis Pizarro. Ainda de Jorge Délano, Ossa cita Luz y sombra, "talvez o primeiro filme anticomunista do cinema chileno"1

"Era dificil, en consecuencia, que a través de un cine paródico se echaran las bases reales para la formación de un verdadero cine nacional. Sin embargo tanbién se apelaba al folletín como fórmula de enternecer a lacrimógenas espectadoras." (OSSA, 1971, pg. 20)

\footnotetext{
1 “tal vez el primer filme anticomunista del cine chileno" (OSSA, 1971, pg. 24)
} 
Uma característica dos anos 20, e talvez a mais importante, é o processo de descentralização da produção cinematográfica chilena: antes concentrada em Santiago, a partir desta década se expande para todo o território nacional.

Um dos filmes mais importantes do período silencioso (não falado) e único conservado inteiro dessa época é El husar de la muerte de Pedro Sienna, realizado em 1925 e restaurado em 1965 nos laboratórios do Departamento de Cine Experimental da Universidad de Chile por Sergio Bravo com a presença do próprio diretor.

El Húsar de la Muerte é considerado um dos filmes mais importantes da história cinematográfica chilena. Em 1995 foi novamente restaurado, desta vez pela Divisão de Cultura do Ministério da Educação, e recebeu nova trilha sonora, com música incidental composta por Horacio Salinas e interpretada pelo grupo Inti Illimani. O filme narra a história do herói nacional Manuel Rodríguez durante as batalhas da Reconquista, até sua morte em 1818. Em 1998, dentro de um programa de rehabilitação do acervo cinematográfico chileno o filme passou a ter o status de Monumento Histórico.

Em 1933 Jorge Délano retorna de Hollywood de onde traz algumas técnicas novas e várias influências infelizes e realiza o primeiro filme falado do Chile, Norte y Sur, financiado pela Caja de Credito Minero.

"El viaje lo hizo Délano no porque el Gobierno estuviera muy interessado en el destino del cine nacional, sino porque su cuñado Pablo Ramírez era ministro y hombre de confianza del general Ibañez”. (OSSA, 1971, pg. 34).

Nesse momento, em que a distribuição cinematográfica já estava totalmente sob monopólio estadunidense, para a desgraça do Cinema chileno pessoas como Jorge Délano, José Bohr e o italiano Eugénio de Liguoro passaram a investir pesadamente no modelo hollywoodiano de produção, com grandes cenários, produção pressa aos caros estúdios e o distanciamento cada vez maior da realidade chilena, com seus romances, comédias e melodramas destinados ao entretenimento e, principalmente, ao lucro. 
"Eugenio de Liguoro, un italiano que habia llegado al pais en busca de posibilidades más o menos concretas, y un poco huyendo de la guerra. Sería el hombre que aportaría un sentido más profesionalizado del cine y el que pautaria los móviles notoriamente comerciales que harian moverse a la industria en los años venideros." (OSSA, 1971, pg. 39).

Paralelamente a esta produção comercial, Armando Rojas Castro e sua equipe continuam a fazer documentários até os anos 40 .

Em outubro de 1938, durante o governo da Frente Popular (Pedro Aguirre Cerda), é criada a CORFO (Corporación de Fomento de la Producción), uma tentativa de alavancar o sistema industrial de produção chileno em diversos setores (aço, petróleo, turismo, cobre, etc) juntamente com políticas de substituição de importação, além de ajudar às vítimas do terremoto de Chillán. Três anos mais tarde, em 1941, com a finalidade de construir e equipar estúdios cinematográficos, é criado uma sociedade anônima, com participação de cerca de $44 \%$ de capital da CORFO: a Chile Films S.A., que entraria em operação definitivamente apenas em 1944, embora tenha tido durante esses anos uma produção bastante regular de noticiários. Ainda durante o governo da Frente Popular, é criada na Universidad de Chile (1940) o Teatro Experimental, que aprimora o trabalho do ator no teatro e será essencial para o desenvolvimento da mise-en-céne no Cinema anos mais tarde.

Com argumento de Francisco Coloane e Carlos Vattier, direção do argentino Luis Moglia Barth e grande elenco, Romance de medio siglo é o filme de estréia da Chile Films, que não conseguiu o público que se esperava e de certa forma deixou os roteiristas um tanto decepcionados.

Entre os anos 1943 e 1944, um fato curioso acontece no cone sul: a Argentina, que se negava a romper relações diplomáticas com o Eixo, se encontrava com sua produção cinematográfica pouco melhor que o Chile, mas devido a sanções internacionais por sua postura política, começa a faltar película. Como o Chile tinha situação econômica estável e facilidades na importação deste material, se estabelece entre os dois países um certo "mercado negro" de película virgem do Chile para a Argentina. 
Na segunda metade da década de 40, com o fim da guerra na Europa e o início da Guerra Fria, as telas chilenas já se encontram ocupadas pelo exército de “divas" e "mocinhos" estadunidenses e a produção local, além de não poder entrar nas salas de exibição, encontra-se com enorme distanciamento da realidade andina, na maior parte das vezes apenas reproduzindo de forma precária um estilo de vida que nada tem a ver com o seu ou com o conjunto latinoamericano, mas sim uma imitação ruim das coisas que saem dos estúdios de Hollywood. Nesse momento a Chile Films se vê imersa em dívidas e a direção da CORFO propõe a sua dissolução. Após intensa campanha midiática, a Chile Films é arrendada por particulares. Em 1947 o então presidente Gabriel González Videla promulga a Ley de Defensa de la Democracia, que coloca o Partido Comunista na ilegalidade e passa a caçar membros da esquerda. O Cinema sofre mais baixas.

Nos anos seguintes, década de 1950, o Cinema chileno vive um tempo de incertezas e obscuridade. Nesse período são finalizados apenas 13 longas, dos quais cinco dirigidos por estrangeiros. O francês Pierre Chenal, recém contratado pela Chile Films, realiza em 1952 El ídolo, e em 1954 Confesión al amanacer, e o espanhol Enrique Vico roda seu único filme como diretor: Llampo de sangre (1954). É dado continuidade àquele velho modo de se fazer filmes, caro, grandes estúdios, glamour e distante da realidade. Para tentar triplar as dificuldades econômicas e técnicas, assim como a falta de investimento e apoio do Estado, realizadores e produtores fundam em junho de 1955 a Diprocine.

A necessidade de inovação na linguagem, a urgência de medidas de proteção em relação ao sistema de distribuição e exibição do filme nacional e a carência de investimentos se tornam evidentes. É, pois, nesse contexto, que surge uma nova geração: Rafael Sanchez e Sergio Bravo começam suas buscas por um Cinema autenticamente chileno, experiências de dentro e fora do Chile começam a aparecer, percebe-se a necessidade de pensar o Cinema em todos os seus níveis, incluindo a processo de formação do cineasta. Uma nova fase se inicia no Cinema chileno. 


\section{Realismo e imagem documental: $O$ momento decisivo}

$\mathrm{Na}$ França, o fotojornalismo moderno ganha impulso a partir dos anos 1950 com a publicação do artigo $O$ momento decisivo (L'instant décisif) de Henri-Cartier Bresson. Nele o autor expõe conceitos importantes sobre a fotografia de reportagem e formaliza diversos procedimentos que já eram utilizados no fotojornalismo, porém de forma apenas "instintiva".

A fotografia de reportagem pode ser uma simples ilustração que acompanha o texto jornalístico, tendo, neste caso, importância secundária em relação ao conteúdo verbal. No entanto, a imagem capturada em determinado momento, com determinada técnica, com recorte adequado e composição coerente pode ser muito mais expressiva e comunicativa que o texto, e muitas vezes até dispensá-lo. A dificuldade encontra-se no aspecto transitório dos acontecimentos e no caráter de instantaneidade do registro fotográfico. Este registro resulta da somatória do objeto ou fato a ser registrado (assunto) e da concepção estética e ideológica do fotógrafo. Em qualquer situação em que se efetua um registro fotográfico a realidade se coloca como um plano quase infinito de possibilidades de enquadramento. $\mathrm{O}$ recorte, inerente à fotografia (os limites do quadro ou da tela), é escolha do fotógrafo, assim como o posicionamento da câmera, a angulação ou o ponto específico para onde se vai mirar a lente. Em um conflito entre uma multidão de manifestantes e uma tropa de policiais, por exemplo, dependendo de que lado se coloca a câmera podemos ter diferentes efeitos ou diferentes significados ou pontos de vista. Neste exemplo, se o fotógrafo escolhe se posicionar junto aos policiais e apontar sua objetiva para o grupo de manifestantes, poderá ter imagens de uma multidão enfurecida e agressiva que precisa ser contida; por outro lado, se a câmera está no meio da multidão, mirando a tropa que vem em sua direção atirando e jogando bombas de forma violenta e sistemática, como é o caso do aparato militar de contenção de massas, teremos imagens de um órgão público se utilizando da força desproporcional e 
financiada por aquela mesma multidão para reprimi-la e forçá-la e recuar. Portanto, a posição de câmera é ideológica. E é também estética, pois além do posicionamento de câmera o fotógrafo terá que recortar, do conjunto que se coloca a sua frente, aquilo que será de fato enquadrado, ou seja, ele escolhe o que deve e o que não deve fazer parte da composição da sua imagem. O recorte, aliás, acontece em dois momentos: primeiro no instante do registro da imagem e, segundo, na escolha das imagens que comporão a reportagem. No caso do Cinema, a montagem.

Cartier-Bresson não aprofunda em seu texto a questão da ideologia na composição da imagem, embora se possam deduzir alguns elementos. Para CartierBresson os elementos envolvidos na operação de registro da imagem; a escolha do tema ou assunto, a composição do quadro, a técnica, a forma de aproximação e relacionamento que o fotógrafo estabelece com o objeto/fato/sujeito, além do instante exato de se disparar o obturador, o que depende basicamente da sensibilidade do fotógrafo e da casualidade dos acontecimentos são os fatores essenciais que determinam a qualidade do resultado obtido. À combinação equilibrada desses fatores ele chama de momento decisivo.

A aplicação do conceito de momento decisivo ao Cinema, sobretudo ao campo documentário, nos parece esclarecedor e nos auxilia na compreensão de cenas como a de Jorge Müller, cinegrafista argentino e fotógrafo de Patrício Guzmán no filme $A$ batalha do Chile, quando filma sua própria morte, assassinado pelos carabineros de Chile em 29 de junho de 1973 durante o Tanquetazo.

Por não se fazer de regras preestabelecidas e não ter as preocupações oficialescas ou institucionais de, por exemplo, os noticiários da primeira metade do século XX que funcionavam como meras propagandas do governo, ou como denomina Paulo Emílio, "rituais do poder", esse novo modo de capturar a imagem, de forma espontânea, livre, aliada ao que veremos mais adiante com o Cinéma Verité de Jean Rouch, com o dispositivo de câmera leva e som sincronizado para imagens em movimento, liberam o cineasta do artificialismo típico da tradição clássica anterior aos Novos Cinemas. Mas essa liberação não se restringe apenas ao campo documentário. No contexto do Nuevo Cine Latinoamericano essa nova estética, do real, do espontâneo, se reflete também, e com mesma intensidade na ficção. Esse realismo quase documental, que tem raízes também no Neo-realismo italiano, fica 
claro nos filmes de Nelson Pereira dos Santos, Alex Viany, Jorge Sanjinés, Miguel Littín e Fernando Birri entre outros, sendo o curta metragem espaço privilegiado para a experimentação e amadurecimento dessa estética. Ao comentar a respeito desse realismo, Glauber Rocha diz se referindo aos filmes de Linduarte Noronha e Mário Carneiro e Paulo Cesar Saraceni respectivamente: "fiquemos certos de que Aruanda quis ser verdade antes de ser narrativa: a linguagem como linguagem nasce do real, é o real, como em Arraial do Cabo" (ROCHA, 2003, pg. 145).

Em Aruanda (1960), produção da Universidade Federal da Paraíba - UFPB - ficção e documentário se mesclam e se confundem. Documentário por que trata de algo objetivo, com dados reais, e representa uma realidade cotidiana do sertão; e ficção do ponto de vista do processo de produção, pois é em parte encenado, reconstituído.

O filme Caliche Sangriento de Helvio Soto (Chile, 1969) é uma reconstituição (ficção, portanto) do episódio que ficou conhecido pelo mesmo nome do filme ocorrido em março de 1879 durante a Grande Guerra do Pacífico, quando o exército chileno enviou para o deserto de Atacama, fronteira com o Peru, milhares de soldados sem água ou comida para uma expedição desastrosa e mortal. O filme inicia-se com imagens de arquivo e fotos de época sobre narração over introduzindo a história. Esse procedimento, típico do documentário, é também outro dispositivo gerador de um certo realismo. 


\section{Fabulação e tomada de posição: Cinéma Vérité}

O campo documentário, território particular, mas não isolado, dentro do universo cinematográfico, tem como uma das principais preocupações a busca da verdade sobre a existência humana, suas relações interpessoais, seu tempo, seus conflitos e contradições. Neste percurso de busca incessante, diversas foram as concepções e pontos de vista acerca do que vem a ser a verdade, seja ela o resultado de uma construção ideológica, uma simples observação do que seria o "real" ou um mosaico de fragmentos e indícios de pequenas verdades.

Nos fins dos anos 50, com a reestruturação alemã, o rompimento com a tradição stalinista, o desmoronamento dos impérios coloniais, a revolução cubana e o início das movimentações estudantis e operárias, Quebec, antes governado pelos conservadores, elege o liberal Jean Lesage, que moderniza a província e acelera seu desenvolvimento, que vai se refletir, entre outras coisas, no surgimento naquele país do "groupe synchrone cinématographique léger".

A criação d'Office National du Film $(O N F)$, órgão governamental, fruto da modernização canadense, da passagem de Grierson por Montréal e da urgência dos movimentos francófonos, traz novos ares à produção cinematográfica daquele país, sobretudo do Cinéma québécois. Neste instituto, em 1956, se inicia a produção de filmes utilizando um magnetofone criado por Charles Beachell conectado e sincronizado com a câmera de $16 \mathrm{~mm}$ e, em meados de 1958, dá-se início à série Candid Eye de entrevistas para televisão, mas ainda dependendo de equipamentos pesados e portanto de difícil locomoção. Mas, o mais importante para o grupo canadense, parece-nos, é o esforço para "donner la parola aux gens", do que o simples uso de novas tecnologias.

No seminário Robert Flaherty, realizado na Université de Californie à Los Angeles (UCLA), Michel Brault apresenta seu recente trabalho, um filme realizado 
por Gilles Groulx sobre um congresso de esquiadores ${ }^{2}$ produzido por Brault, Groulx e a equipe d'ONF. Tal filme irá impressionar tanto Richard Leacock, fotógrafo e corealizador de Primaires (1960) e de Crise (1963), dois ícones do Direct estadounidense, quanto o francês Jean Rouch, que desde o início dos anos 50 já vinha experimentando formas de dar voz aos povos da África negra colonizados pelos franceses, em meio ao turbilhão das guerras de independência.

Voilá, o equipamento técnico (o "groupe synchrone cinématographique léger") utilizado no filme de Groulx era justamente o que Rouch precisava para, juntamente com o sociólogo Edgar Morin, colocar em prática o que ele chamaria de Cinéma Vérité, projetado em 1960-61, em Chronique d'un été, filme que contou também com Brault, que se desloca para a França e, mais tarde, trabalhará com Mario Ruspoli, defensor do Direct na França.

Em 1963 acontece o encontro paralelo ao MIPE-TV (Marché International des Programmes et Équipements de Télévision) onde duas correntes cinematográficas distintas irão se encontrar e entrar em conflito. De um o filmereportagem dos heróis "americanos" de Drew, de outro, o filme-fabulação dos antiheróis-modelos de Rouch.

De certa forma, num primeiro momento, poderíamos dizer, grosso modo, que essas duas correntes seriam ramificações do Cinema direto apresentado pelos canadenses no seminário Robert Flaherty. No entanto, não se trata de dois ramos daquele, mas de três pontos de vista distintos e três formas de utilização do suporte cinematográfico que se desenvolvia então. Nos três países em questão, Canadá, Estados Unidos e França, já havia, antes do referido seminário, manifestações rumo ao direto. A esse respeito, Guy Gauthier nos esclarece:

Cette concentracion n'est pas um hasard. Elle s'est faite sous l'emblème de Flaherty, par le biais des séminaires de l'UCLA, dans trois pays bénéficiant d'une bonne technologie, d'une tradition solide, et d'une grande liberté de mouvement, limitée seulement par la suspicion des

\footnotetext{
${ }^{2}$ GROULX, Gilles. Les Raquetteurs. Québec, Canadá: 1959.
} 
décideurs économiques. Experience historique - progrès technique - liberté de création : c'est l'autre triangle qui pourrait définir cette période.

Peu de pays au réunissaient ces conditions, d'où la concentration géographique de cette explosion du direct. Le reste du monde ne manquait pas pour autant de talents, ni de causes à défendre, mais, le sousdéveloppement, l'indifférence au genre documentarie, les restrictioins des libertés, manques de tribune internationale ont condamné la plupart des pays, soit à suivre le mouvement en dépit des difficultés, soit à définir une autre voie, quelquefois contre le modèle dominant. (GAUTHIER, 1995, p. 71)

Além das condições favoráveis expostas, há uma característica comum entre eles, que poderia colocá-los num mesmo "grupo": o conceito, segundo Ruspoli, de "Cinema Direto": uma técnica (equipamento leve e sincrônico e película $16 \mathrm{~mm}$ sensível), um método de filmagem (sem roteiro, câmera na mão, som direto etc) e uma estética (“do real”). (PARENTE, 2000) Mas, apesar dessa aparente proximidade, a única ligação entre eles é a contemporaneidade, o equipamento técnico e o fato de seus principais representantes terem se encontrado naquele evento.

O direto estadunidense, representado por Robert Drew e Leacock surge de uma incapacidade da televisão de se desvincular da tradição radiofônica da locução de um texto narrativo, mas ilustrada com imagens que legitimem os argumentos narrados. A partir disso, a idéia de Drew e Leacock era de fazer um filme "sem a intervenção" do realizador, que pudesse captar o real de forma o mais "pura" possível e mostrá-la ao espectador através apenas das imagens, ações e falas naturais dos personagens sociais.

Cinema que se acreditava, num primeiro momento, capaz de prescindir da representação/da encenação, em frente às câmeras e capaz, portanto, de apontá-las para a realidade e captá-las sem interferência. (REZENDE, 2001, p. 184) 
Leacock seria, segundo Marcorelles, o homo-cinematográphicus, (PARENTE, 2001) enquanto para nós, ele só poderia ser um grande aficionado por televisão e que viu na somatória deste meio de comunicação com a nova tecnologia que estava surgindo uma ótima oportunidade para ganhar fama e dinheiro fácil. Em Crise, (DREW, 1963) os "heróis" de Leacock e Drew são o “excelentíssimo presidente da república dos Estados Unidos da América" e seu subordinado, o “excelentíssimo senhor procurador-geral da república dos estados unidos da América”. Por que não os dois alunos negros (Vivian Malone e James Hood) que são, de fato, os que sofrem todas as ações? O filme de Drew poderia, ao invés de acompanhar os "bem-nutritos tomadores de decisão", acompanhar o sofrimento e a tensão dos dois estudantes, que ao acordarem no dia da matrícula não sabem nem mesmo o que os espera na porta da universidade. Talvez saibam menos ainda que se tornaram não garotos propaganda de suas causas, mas de fantoches de uma política hipócrita e mesquinha, numa situação que só uma sociedade absurdamente atrasada do ponto de vista humano poderia estar, uma sociedade apodrecida pela ganância, pela mentira e pelo conservadorismo medíocre, do qual Drew e Leacock são produtos e representantes.

O direto dos Estados Unidos se diferencia pouco do seu primo mais velho, a indústria de Hollywood. Se o enlatado da indústria de sonhos (e de pesadelos) de Hollywood tem seu produto meticulosamente planejado, ensaiado, padronizado e com o mínimo de improvisações, além de contar com grandes "estrelas" sorridentes (na tela, mas que nem sempre o são fora dela), o produto de Drew-Leacock tem apenas algumas adaptações: é igualmente planejado, mas não ensaiado, pois depende da sorte de que aconteça algo grandioso diante da câmera; segue os mesmos padrões de representação e de narração através da ação e tem muito mais (quantitativamente) improvisos. No caso das "grandes estrelas", estão presentes: o presidente, o procurador-geral, o chefe do FBI, etc. Enfim, “(...) um cineasta como Leacock é profundamente hollywoodiano, mesmo se ele prescinde de certas convenções (industriais, técnicas e narrativas) hollywoodianas". (PARENTE, 2000, p. 113)

$\mathrm{Na}$ linha de produção Drew-Leacock até o "real" deixa de ser realidade. A presença da câmera, por menor e mais leve que seja e a equipe de filmagem, mesmo que brutalmente reduzida, não impede a teatralização dos personagens, pelo 
contrário, ao ter consciência de estar sendo filmado, o personagem dramatiza suas ações a todo instante, dando a impressão de que estamos mesmo diante de um desses filmes quaisquer de ficção de mocinho e bandido. Em alguns momentos de Primárias (DREW, 1960) e de Crise a voz over se faz necessária para dar impulso dramático à narração.

O Cinema proposto por Rouch, contrariamente àquele fabricado por Robert Drew, não tenta esconder a câmera nem seu realizador, mas sim os utiliza como provocador dos acontecimentos. "Se a neutralidade da câmera e do gravador era uma falácia, para que tentar dissimulá-los? Por que não utilizá-los como instrumentos de produção dos próprios eventos, como meio de provocar situações reveladoras?” (DARIN, 2006, p. 149)

O Cinema rouchiano (Cinéma Vérité) privilegia o modo interativo e compartilhado de representação. O realizador passa a ser também "ator" e o personagem fabula sobre si mesmo e sobre seu meio, nos revelando verdades implícitas e que, às vezes, nem mesmo ele tem consciência de sua existência, como em Moi, um noir, (ROUCH, 1958) em que Robinson se reinventa a si mesmo a partir dos elementos que o formou como pessoa: a influência perversa do cinema hollywoodiano no imaginário de seu povo, a colonização desastrosa que destrói sua cultura e implanta valores externos, o desejo de ter algo inalcançável pela simples ilusão do consumo, o parecer ao invés de ser.

Para se chegar ao modelo de Moi, um noir e depois em Chronique d'um Été, Rouch percorreu longo caminho de experimentação, busca e aprendizagem. Antropólogo de formação, iniciou sua carreira cinematográfica meio por acaso, utilizando o registro fílmico ao invés do tradicional bloco de notas. A partir de expedições de caráter científico à África negra, começou seus registros procurando de alguma forma representar a população visitada do modo mais natural possível.

Com o auxílio do Institut Français d'Afrique Noire e do Musée de l'Homme de Paris, filma Cimetieres dans la falaise, 1950-51, onde a banda sonora é um misto de música típica da população retratada, voz over que narra os acontecimentos e um baixo, precário e dessincronizado som direto. No caso da música, presente quase todo tempo, parece transparecer a vontade do autor de incluir no filme a "voz" dos personagens, mesmo que de forma apenas simbólica. A narração, também over, de 
Les maîtres fous, 1955, filme produzido com o apoio do Centre National de la Recherche Scientifique (1955), inclui trechos de interpretação das falas (sem som direto) dos personagens. Percebe-se aqui o desejo de Rouch de que o espectador saiba quais são os diálogos travados pelos "mestres", recriando-os de forma indireta, mas sem dublagem. Esse filme registra um ritual religioso dos haoukas, ${ }^{3}$ etnia originária da região do mar Vermelho que após longo percurso imigratório se fixaram em "Acra, capital da [então] Costa do Ouro". O que nos chama a atenção neste ritual são a criação e personificação espontânea de personagens pelos próprios integrantes da seita, fazendo da cerimônia uma espécie de teatro, uma "fícção real" na medida em que, a princípio, o encontro é verdadeiro. Mais do que isto, como bem nos lembra André Bazin,

\begin{abstract}
"esse culto que nasce, cujo ritual ainda inseguro vai se fixando a cada cerimônia, adota, como gênios e deuses, não os gênios e deuses da floresta ou das águas, do fogo ou da chuva, mas os mitos da potência colonialista segundo a experiência pessoal dos negros. Ou seja, o 'governador', o 'médico', a 'mulher do médico', o 'maquinista do trem' ou ainda a 'sentinela' e muitos outros". (2006)
\end{abstract}

Ou seja, esses personagens assumidos pelos devotos são, na verdade, representações dos colonizadores.

A fabulação começa a tomar corpo em Moi, un Noir, que contou com a ajuda do Service d'Information de la Côte d'Ivoire e da Fraternité Nigérienne d'Abidjan, história contada por Robinson a partir da narração improvisada sobre a reinvenção do material já filmado e posteriormente projetado. Nele, caubóis de faroeste,

${ }^{3}$ Haouka, segundo nota do editor de Os mestres loucos, de André Bazin, publicado no encarte do DVD do filme Les maîtres fous, no Brasil: "é uma palavra da língua hauçá (haoussa, em francês). Como J. Rouch comentou mais de uma vez, pode significar 'mestre ou senhor do vento' e 'mestre ou senhor da loucura"". 
"Treichville, a Chicago da África Negra" e Constantine, o "agente-federalamericano", se misturam e explicitam a dominação do imaginário cinematográfico daquela população.

Chronique d'un Été foi uma tentativa de colocar em prática os conceitos desenvolvidos por Morin em seu artigo Pour un Nouveau Cinéma-Vérite, ${ }^{4}$ publicado alguns meses antes. Na abertura do filme, sobre imagens de populares circulando nas ruas de Paris, ouvimos a voz off de Jean Rouch: Este filme não foi representado por atores, mas vivido pelos homens e mulheres que dedicaram momentos de suas vidas a uma experiência nova de cinema-verdade. (DA-RIN, 2006, p. 150)

Resultado dessa longa trajetória de experimentação, somada com a experiência do canadense Michel Brault e do sociólogo Edgar Morin, esse filme se compõe de entrevistas, discussão coletiva e projeção do próprio filme para receber as críticas e opiniões dos personagens. Nele, a proposta do Cinéma Vérité se concretiza, mesclando realidade e fabulação, verdades e imaginação, êxito e fracasso na proposta. Segundo o próprio Morin:

“(...) é um filme em que não há lutas, não há tiros de revólver, não há beijos (isto é, quase nenhum). No fim das contas, a ação é a palavra. A ação é passada pelos diálogos, pelas brigas, pelas conversas. O que me interessa não é um documentário que mostre as aparências, mas uma intervenção ativa que vá além das aparências, para extrair as verdades ocultas ou adormecidas." (2008, p. 32)

Em Jaguar, 1967, que representa uma viagem fictícia, mas real, de três jovens que deixam sua terra (Níger) para se aventurar atrás de trabalho e renda na Costa do Ouro, o recurso da fabulação é levado ao extremo. A viagem de fato aconteceu, mas cada um dos três personagens é a encarnação de sua própria imaginação, nos revelando pequenas verdades sobre si mesmo misturadas com mentiras sinceras do imaginário popular local. O profundo respeito a outras etnias

\footnotetext{
${ }^{4}$ France-Observateur, 14 jan. 1960.
} 
locais e a forma irônica com que os personagens tratam o invasor (o policial inglês da alfândega) expõe um pouco do sentimento contido de cada um.

Visto assim, o Cinéma Vérité, nos parece, vem justamente nos mostrar a impossibilidade de se encontrar uma verdade absoluta, que sirva a tudo e a todos ao mesmo tempo, sobretudo quando esta verdade é algo construído e extremamente manipulado por um autor ou uma equipe, seja no processo de produção, seja na mesa de montagem, ou mesmo na direção da leitura no momento de sua projeção, independente do equipamento técnico utilizado:

“(...) a ruptura que se produziu por volta dos anos 60, com o cinema de Cassavetes, Clarke, Perrault e Rouch, não é entre a ficção e a realidade, mas em um novo modo de narrativa que se libera do modelo de verdade e encontra a função de fabulação que se opõe a esse modelo." (PARENTE, 2000, p. 127)

Assim, a importância do Cinema direto, mas mais precisamente o Cinéma Vérité, é a de demolir a fronteira entre ficção e documentário, e assim abrir espaço para novas formas de representação, distanciadas do modelo até então hegemônico, além de incorporar novas técnicas e estabelecer uma nova estética. Luiz Augusto Rezende aprofunda essa discussão quando nos propõe que

“(...) a tendência ao desvio pelo direto que Comolli detecta no cinema é menos uma adesão mais generalizada a uma técnica ou a uma nova tecnologia do que o produto de uma nova concepção da realização cinematográfica - a qual não mais pretende extirpar o presente da filmagem da futura imagem registrada, mas, ao contrário, incluí-lo como elemento agenciador plenamente perceptivel dessa imagem." (2001, p. 186. Grifo do autor)

E, ainda,

"Se o processo de obtenção de uma imagem podia servir como traço distintivo do domínio documentário/ficção, ele não poderá fazê-lo a partir do momento em que se percebe que improviso e encenação estão juntos no processo de qualquer filmagem, que o presente vivo da filmagem pressiona, 
a todo tempo, o presente da narração, e que qualquer imagem é, portanto, ambivalente, não importa como foi obtida, ela sempre será, por um lado, ficção e por outro, documento. É o regime discursivo em que ela se encontra que definirá (ou não) qual dessas suas acepções (documental ou ficcional) deve afluir à superficie para completar o seu sentido e o sentido do discurso a que ela se serve.” (idem)

Gauthier nos lembra ainda o fato de que

"(...) vers 1930, l'invention du parlant modifia radicalement le cinéma de fiction, sansdonner la même chance au cinéma documentaire; vers 1960, le perfectionnement $d u$ parlant par le direct hors studio, donna pratiquement un résultat inverse. Les nouvelles orientations du cinéma dans son ensemble (cf. Louis Marcorelles) montrèrent que le direct avait été une leçon pour tout le monde." (1995, p. 76)

Fabricação de consenso e provocação de dissenso: construção artificial de uma verdade unilateral e procura de uma verdade relativa discutida coletivamente, eis a grande diferenciação entre Rouch e Drew.

Influenciado pelo Cinema direto, sobretudo pelo Cinéma Vérité e pelo free cinema inglês, na América Latina vão aparecer novas formas de se fazer e de pensar Cinema:

"Pero el empleo de esos equipos ligeros tienen otras consecuencias más importantes. Es posible, gracias a ellos, darle una mayor movilidad a la cámara, pues ésta se utiliza en muchos casos en la mano, sin necesidad de otro soporte.” (ALEA, apud PARANAGUÁ, 2003, p. 453)

O uso de equipamentos mais leves e sincrônicos, seja no documentário seja na ficção, permite, obviamente, maior liberdade do realizador, baixa os custos e traz a possibilidade de desenvolvimento de cinematografias particulares, de certa forma até autorais, abrindo caminhos para Cinemas que não teriam sequer como existir no mercado dominado pelos enlatados estadunidenses. 
A emergência de um Cinema documentário militante e extremamente produtivo na América Latina não é pura coincidência, mas reflexo e produto dos diversos fatores que se conjugam no início dos anos sessenta, a começar pela revolução Cubana: políticas de dominação do subcontinente por parte dos Estados Unidos com as conseqüentes ditaduras locais, facilidades de produção a partir do surgimento do "groupe synchrone cinématographique léger" e de diversos manifestos de importantes cineastas latinoamericanos: Fernando Birri (El manifesto de Santa Fe - Argentina, 1962), Jorge Sanjinés (Teoría y práctica de un cine junto al pueblo - Bolívia, 1972), Santiago Álvarez (Arte y compromisso - Cuba, 1968), Fernando Solanas e Octavio Getino (Prioridad Del documental - Argentina, 1971).

A preocupação deixa de ser técnica e passa a ser ideológica, conforme se vê nas palavras de Jorge Sanjinés:

\footnotetext{
“(...) en Bolivia la muerte y la miseria golpean los ojos y los oídos minuto a minuto, y los hombres inquietos que lanzan una pregunta reciben a gritos la respuesta. Poco a poco se estructuró la idea del papel que debería jugar un cine nacional en un pais pobre. "
}

A semente do Cinema direto germina em solo latino-americano, mas adquirindo novas características, confluindo, discordando, de forma antropofágica se alimentando das novas tecnologias colocadas, da nova estética e método, e vomitando outros conceitos, outras formas de pensar.

\footnotetext{
${ }^{5}$ SANJINES, Jorge. Teoría y práctica de un cine junto al pueblo, 1972 (Manifesto)
} 


\section{Picardia e antropofagia no cone sul: o Nuevo Cine Latinoamericano}

Ao retornar da Itália, em 1954, após estudar no Centro Experimental de Cinematografía de Roma (Centro Sperimentale di Cinematografia), Fernando Birri acompanhou as transições políticas sofridas pela Argentina e fez parte do grupo de discussão e planejamento do governo de Arturo Frondizi. No Instituto Social da Universidad del Litoral (província de Santa Fe), onde havia estudado e dirigido um grupo de teatro amador antes de ir para a Europa, organizou um seminário de Cinema e formou, entre os estudantes de Ciências Sociais, um pequeno grupo com a proposta de criar painéis de foto-entrevistas da região de Santa Fé. Com o amadurecimento do grupo e o reconhecimento da universidade, fundou em 1956 o Instituto de Cinematografía de Santa Fé da Universidad Nacional del Litoral, também conhecido como Escuela Documental de Santa Fé.

Uma das primeiras experiências cinematográficas do Instituto foi um documentário resultante da ampliação do projeto de foto-entrevistas: Tire dié (BIRRI, 1958). Considerado o marco inicial do Nuevo Cine Latinoamericano, o filme mescla material documental, voz over, cenas fictícias e entrevista. Dois planos chamam a atenção: o plano inicial, aéreo sobre a província de Santa Fé, o narrador descarrega uma série de dados geográficos e estatísticos sem dar tempo ao espectador para processar tais informações. A tabulação desses dados, extremamente racional perde totalmente a racionalidade ao ser colocado um após outro, sem nenhuma conexão aparente, formando um mosaico de grandeza e vazio. O outro plano, é o dos garotos que correm junto ao trem sobre uma ponte quase sem chão pedindo dinheiro aos turistas. 
A poesia absurda da imagem dos meninos e meninas que arriscam a vida para tentar ganhar dez centavos (o termo "tire dié" é uma contração de "atire dez centavos") é carregada de racionalidade crítica. Em 1962 Birri escreve "Cinema $e$ subdesenvolvimento".

Além de Fernando Birri, estudaram no Centro Experimental de Cinematografia de Roma os cubanos Tomás Gutiérrez Alea, Gabriel García Márquez, e Julio García Espinosa. O contato desses cineastas com o Neo-realismo italiano, movimento que propunha uma nova concepção de Cinema, terá reflexos não só no modo de se fazer Cinema, mas principalmente de se pensar Cinema. Inovação na linguagem, locação ao invés de estúdios, trabalho diferenciado com o ator (e também com não-atores), a mise-èn-cene, a maior utilização de luz natural e, principalmente, a temática social em primeiro plano, são influencias que estes cineastas trazem da Itália e colocam em xeque a estrutura de produção baseada no modelo hollywoodiano predominante no pensamento colonial latino-americano de então. A liberdade na inventividade da linguagem e da temática no documentário cubano, sobretudo no ICAIC, resultado do clima revolucionário que Cuba vivia aliado à estética realista e a poética social vindas do Neo-realismo coloca o Cinema cubano e argentino, através de Fernando Birri, na vanguarda do Cinema latinoamericano.

No início da década de 1960 as idéias de um novo Cinema já percorria toda a América Latina. Brasil, Venezuela, Chile, México e Bolívia, além da Argentina e Cuba são os principais países.

A prática cinematográfica nesses países é cada vez mais ligada á teoria de um Cinema abertamente revolucionário.

"Los objetivos no fueron tan precisos como lo son hoy, y fueron recortándose de la propia experiencia respecto de la realidad objetiva; resultaron necesariamente ligados al interés de las mayorías desposeídas y se establecieron como metas de lo que se entendió como la responsabilidad del artista, del intelectual, que debía, en buena parte, su propia condición de privilegiado al desgaste, al hambre, al exterminio de esas mayorias. El proceso y convulsión social que desencadenó la revolución de 1952 tuvo 
mucho que ver con la toma de conciencia de los cineastas comprometidos, como se vera mas adelante.

De esa conciencia, que se convierte en compromiso con la causa del pueblo, nace una actitud militante en estos cineastas que se deciden a hacer un cine comprometido, político, urgente y combatiente." (SANJINÉS, 1972)

A partir dos manisfestos o Cinema passa a ser visto como uma arma, que assim como fusil deve ser utilizado no processo de libertação dos povos latinoamericanos.

"Ahora se hace necesario considerar el paso de este cine revolucionado de la defensa a la ofensa. El cine quejumbroso, llorón y paternal del comienzo pasó a ser un cine ofensivo, combatiente y capaz de asestar golpes contundentes al enemigo." (SANJINÉS, 1972)

O inimigo: a clase dominante, entreguista e submissa; e o imperialismo (neo) colonizador. Os cineastas percebem que a estratégia não é mostrar a miseria e o subdesenvolvimento à população, pois isto o trabalhador conhece no seu dia-a-dia. É preciso mostrar o sistema de relações que propiciam o estado de miseria e exploração. Trata-se de apresentar as causas, não os efeitos.

A predominância do formato documentário está ligada ao fato de a ficção, por uma limitação formal, não conseguir provar, documentalmente, os fatos e as interligações do sistema. Porém, o Nuevo Cine Latinoamericano, como o fez o Cinéma Verité de Rouch, implote as limitações e fronteiras entre os formatos e ignora o sistema de gêneros que só funcionam na indústria fordista hollywoodiana. 


\section{Sonho e militância: o Cinema da Unidad Popular}

Um dos grandes entraves para o desenvolvimento cinematográfico chileno (e também na América Latina) desde o princípio foi a falta de uma estrutura de formação. Em 1929 foi criado no Chile o Instituto de Cinematografía Educativa, voltado sobre tudo para o noticiário. Experiência não bem sucedida foi abandonada rapidamente. Apenas em 1955 é criado o Instituto Fílmico, ligado à Universidad Católica, por Rafael Sánchez. Este instituto tinha como prioridade a formação voltada para o campo documentário. Abrindo-se para a ficção apenas a partir de 1970, quando o instituto passou a integrar a recém criada Escuela de Artes de la Comunicación. Entre os primeiros formados estão Patrício Guzmán, que depois segue para a Escuela Oficial de Cinematografía de Madrid a fim se aperfeiçoar e Sérgio Bravo.

Dois anos após a criação do Instituto Fílmico, surge na Universidad de Chile, a partir da experiência do Cineclube universitário, o Centro de Cine Experimental, (fundado por Sergio Bravo e Pedro Chaskel en 1957), depois rebatizado Departamento de Cine Experimental. Esse mesmo departamento seria alguns anos mais tarde o principal formador dos cineastas da Unidad Popular. Carlos Flores, Héctor Ríos, José Román e Sergio Castilla são alguns dos que se formaram ali.

Na Universidad de Chile sede Valparaíso é criada em 1968 a Escuela de Cine, a qual formou 16 cineastas, produziu 8 documentários em $16 \mathrm{~mm}$, além de dar origem ao Festival de Cine Latinoamericano e colaborar na 
fundação do Departamento de Cine de la CUT.

Durante o governo do democrata-cristão Eduardo Frei (1967) a indústria cinematográfica passa a receber investimentos através da Diprocine, em associação com realizadores e produtores. Como resultado da emergência do Cinema militante no Brasil, Argentina e Chile e a eclosão de documentários produzidos na Chile Films e na Universidad de Chile e o crescente intercâmbio entre realizadores de todo o continente, mas sobretudo do cone sul, nasce o Festival de Cine Latinoamericano de Viña del Mar, onde seria apresentado o Manifiesto de los Cineastas de la Unidad Popular, manifesto base em torno do qual se reuniram aqueles que transformariam radicalmente o Cinema chileno e trabalhariam em prol da conscientização popular e dos esforços de divulgação da revolução pacífica de Salvador Allende.

No Festival de Cine Latinoamericano de Viña del Mar é apresentado Três tristes tigres (1968) de Raoul Ruiz e O Chacal de Nahueltoro (1969) de Miguel Littin.

De caráter explicitamente socialista, o Cinema da Unidad Popular acampanhou todo o processo, desde as eleições de Salvador Allende até muito depois do golpe militar de Augusto Pinochet. Em 1962, o holandês Joris Ivens filme ...A Valparaíso, uma homenagem poética à cidade na mesma linha de La Seine a recontré Paris (France, 1957) e em 1964 Le train de la victoire, acompanhando o trem utilizado pela campanha eleitoral de Salvador Allende que cruza o país andino. Os dois filmes serviram de escola para os cineastas da Unidad Popular. Em ...A Valparaíso trabalharam: Luis Cornejo (produção), Sergio Bravo, Augustin Altez, Rebecca Yanez, Joaquin Olalla e Carlos Böker (assistentes de produção), Georges Strouvé (direção de fotografia), Patricio Guzmán e Leonardo Martinez (assistentes de fotografia), Jean Ravel (montagem) e Gustavo Becerra (música). Teve ainda a participação de Chris Marker, cineasta francês que teve imensa importância na cinematografia chilena durante o governo de Allende e depois do golpe no Cinema Chileno de Exílio.

As temáticas do Cinema da Unidad Popular serão os mais diversos, porém, os temas mais abordados são a conscientização política do processo revolucionário rumo ao Socialismo; a questão do alcoolismo, que era um problema de saúde pública muito grave na época; a religiosidade; os povos originários; filmes educacionais e de 
alfabetização; história dos movimentos populares e reportagens sobre a situação latinoamericana, visto que na época (1967-1973) diversos países da América Latina encontram-se sob ditaturas militares, todas com auxílio da $C I A$ e encabeçados por militares formados na Escola das Américas, centro de treinamento estadounidense anti-guerrilha e preparatório para intervenções militares.

O realismo na literatura, que aparece no Chile a partir da "geração de 38", terá reflexos claros no Cinema da Unidad Popular, assim como a Nueva Canción, sendo comum inclusive os filmes terem como trilha sonora músicas de Inti Illamani, Victor Jarra e Violeta Parra. No filme Venceremos de Pedro Chaskel e Héctor Ríos (1969-70) a música de mesmo nome que se tornou hino do movimento revolucionário é cantado pelo próprio povo.

O Departamento de Cine Experimental da Universidad de Chile, assim como Escuela de Cine também da Universidad de Chile sede Valparaíso foi imediadamente fechado após o golpe militar, enquanto que a Escuela de Artes de la Comunicación da Universidad Católica encerrou suas atividades em 1979 pelos religiosos em comunhão com os militares. 


\section{Considerações finais}

De um modo geral, os Cinemas latinoamericanos, desde o início estiveram condenados a precariedade, ao subdesenvolvimento e a submissão aos interesses estrangeiros, apenas reproduzindo estereótipos e modos de vida e cultura alheios a realidade local. A necessária libertação desse estigma jamais poderia acontecer por benevolência do império de Hollywood ou das elites locais.

Os Cinemas novos das décadas de 60 e 70 na América Latina, se utilizando as mais diversas estratégias de produção, conseguiram, se não a independência total do sistema internacional, pelo menos grande liberdade inventiva e inovações de linguagem, além de, alguma forma, dialogar com o seu público. Poderíamos falar de influências. Que o Cinema latinoamericano daqueles anos era influenciado pelo Neorealismo italiano, pelo Cinéma Verité ou pela Nouvella Vague, mas não acreditamos que seja o caso. Os meios de produção no que dizem respeito ao aparato técnico, ou seja, o surgimento do som direto sincronizado, das câmeras leves, da possibilidade de se filmar nas ruas, isso tudo está relacionado desenvolvimento tecnológico de cada época. E os equipamentos são os mesmos, ou pelo menos quase os mesmos, em qualquer parte. De acordo que é desenvolvido um novo equipamento, a tendência natural, até pelo fato de estar em um mundo (infelizmente) capitalista, é dos equipamentos se espalharem como se fossem mercadorias. E, um dia, chegará mesmo aos cantos mais distantes ou isolados.

O Nuevo Cine Latinoamericano, ou talvez fossem os Nuevos Cines Latinoamericanos, por que apesar de certa unidade também temos infinitas diferenças, se faz justamente da diversidade e é resultado, sobretudo, de uma história que é única no planeta, que é a história dos países da América Latina, com suas multiplicidades, contrastes e igualdades e diferenças. Certamente o fato de vários cineastas que integraram o "movimento" terem se formado total ou parcialmente na Itália, na França, na Inglaterra ou na Espanha, trouxe, além da herança ibérica que já temos desde a colonização das Américas, 
idéias, concepções, teorias e, até, influencias, do continente europeu. Mas com certeza o Cinema que se fez, e se faz, aqui é absolutamente outro. Pelo simples fato de sermos, nós latinoamericanos, outros povos que não aqueles. Isso, nos Novos Cinemas produzidos aqui, nas Américas, fica muito claro.

Ao analisarmos os filmes Elecciones de Mario Handler e Ugo Ulive (Uruguay, 1967), produção do Instituto de Cinematografia de la Universidad de la República e Venceremos de Pedro Chaskel e Héctor Ríos (Chile, 1970), é evidente a diferença de perspectiva. Os dois filmes documentam o processo eleitoral, cada um no respectivo país, ambos são produzidos no meio universitário, relativamente na mesma época e sob um regime (ainda) democrático, mas a visão que se tem dos possíveis resultados são bastante distintos. No Chile, por exemplo, a eleição de 1970 definiria entre continuar vivendo no modo capitalista de organização ou cambiar radicalmente rumo ao Socialismo, enquanto que no caso uruguayo as eleições mudaria os mandatários, mas o sistema, a princípio, continuaria o mesmo. Os cineastas chilenos apostaram na mudança, até por que faziam parte dessa mudança. $\mathrm{E}$ o que sucedeu após as eleições foi justamente uma mudança radical também nos meios de produção cinematográfica. Tal mudança aproximou, estética e ideologicamente e em relação à liberdade de criação, o Cinema chileno do cubano. Os traços em comum observados entre o Cinema cubano e o chileno no período aqui estudado, são, na nossa avaliação, muito maiores do que entre o chileno e o brasileiro, por exemplo, salvo as diferenças óbvias de idioma e de cultura, lusa e hispânica. Ou mesmo entre o chileno e o argentino. No nosso entender, a base dessas diferenças encontra-se na mudança de paradigma social. Nos Cinemas dos países latinoamericanos, de uma forma geral, o que se colocava era a necessidade de transformação da sociedade. Nos casos de Chile e Cuba, a preocupação dos realizadores estava mais na construção da nova sociedade que nascia. Em La hora de los hornos de Fernando Solanas e Octávio Getino (Argentina, 1969) o filme é introduzido informando o espectador que o que ele verá no transcorrer do filme se refere à Argentina, mas é aplicável ao conjunto latinoamericano, com exceção de Cuba, "único país liberado" do sistema capitalista de exploração. Se o filme de Solanas e Getino fosse feito após 1970, provavelmente o Chile entraria na exceção, ou pelo menos haveria uma ressalva. 
Estando os dois países, Chile e Cuba, livres do sistema econômico perverso que é o capitalismo, ao pelo menos rumo a isso, pois sabemos que no caso chileno a revolução não se concretizou, a liberdade de criação e o sentido do fazer Cinema é outro. O que acontece depois, em setembro de 1973 no Chile do ponto de vista da produção cinematográfica é justamente a desilusão de tudo o que estava sendo construído. Um dos primeiros atos dos pacos e soldados de Pinochet foi o incêndio da Cinemateca chilena, que até hoje não conseguiu restabelecer seu acervo. É a destruição da história simbólica do país. Após o golpe, o Cinema chileno quase desapareceu sob a ditadura, com a maior parte dos cineastas exilados e a estrutura produtiva desarticulada.

Atualmente, o Cinema chileno passa por nova reestruturação, apesar de os fantasmas de Pinochet ainda rondarem por lá. O que se observa no Cinema atual do país irmão é a herança do Cinema militante, refletido em filmes como Machuca (2004) de Andrés Wood ou mesmo Dawson, Isla 10 (2010) do próprio Miguel Littín, mesclado com novos ares de "redemocratização", como Grado 3 de Roberto Artiagoitía (2009). 


\section{Bibliografia}

AUMONT, Jacques e outros. A Estética do Filme. Campinas: Papirus, 1995.

AVELlar, José Carlos. A ponte clandestina: Birri, Glauber, Solanas, García Espinosa, Sanjinés, Alea. São Paulo: Edusp, 1995.

BALTAR, Mariana. A evidência do audivel: o som documental e a tradição intervencionista no documentário brasileiro. In: CARDOSO, Juliana; BOUILLET, Rodrigo; ADES, Eduardo et BRAGANÇA, Gustavo. O som no cinema. Rio de Janeiro: Tela Brasilis, 2008.

BASTOS, Baptista. O filme e o realismo. Porto: Nova Crítica, 1979.

BAZIN, André. Les maîtres fous de Jean Rouch. In: Encarte do DVD Moi, un noir \& Les maîtres fous, lançado pela Vídeo Filmes, em 2006.

BERNARDET, Jean-Claude. A entrevista. In: CARDOSO, Juliana; BOUILLET, Rodrigo; ADES, Eduardo et BRAGANÇA, Gustavo. O som no cinema. Rio de Janeiro: Tela Brasilis, 2008.

BERNARDET, Jean-Claude. Cineastas e imagens do povo. São Paulo: Companhia das Letras, 2003.

BERNARDET, Jean-Claude. Cinema brasileiro, proposta para uma história. Rio de Janeiro: 1979.

BERNARDET, Jean-Claude. Historiografia clássica do cinema brasileiro. São Paulo: Annablume, 1995.

BIRRI, Fernando. Soñar com los ojos abiertos: las treinta lecciones de Stanford. Buenos Aires: Aguilar/Altea/Taurus/Alfaguara, 2007.

CAETANO, Maria do Rosário. Cineastas latino-americanos. Entrevistas e filmes. São Paulo: Estação Liberdade, 1997.

CANCLINI, Nestor Garcia. Culturas híbridas: estratégias para entrar e sair da modernidade. São Paulo: EDUSP, 1998

CAPELATO, Maria Helena (et al.). História e cinema. São Paulo: Alameda, 2007.

CARDOSO, Maurício. O cinema tricontinental de Glauber Rocha - política, estética e revolução (1969-1974). Tese de doutorado sob orientação de Dra. Zilda Márcia Grícoli Iokoi (USP) e Dra. Idelette Muzart (Paris X), 2007. 
CARTIER-BRESSON, Henri. El instante decisivo. In: FONCUBERTA, Joan (org.) Estética fotográfica. Barcelona: Blume, 1984

CLOUZOT, Claire. Le Cinéma français depuis la Nouvelle Vague. Paris: Fernand Nathan/Alliance Française, 1972.

DA-RIN,Silvio. Espelho partido. Rio de Janeiro: Azougue Editorial, 2006, $3^{\text {a }}$ edição.

ESTÈVE, Michel. Le Cinéma Nôvo Brésilien. Paris: Études cinématographiques, nº3-96 (1972) e 97-99 (1973).

FABRIS, Mariarosaria. Mapeando a América Latina. In RAMOS, Fernão Pessoa, CATANI, Afrânio, GATTI, José, MOURÃO, Maria Dora (org.). Estudos de cinema 2000 - Socine. Porto Alegre: Sulina, 2001.

FERREIRA, Alexandre Figueirôa. La vague du Cinema Novo en France fut-elle una invention de la critique? Paris: L'Harmattan, 2000.

FRANCIA, Aldo. Nuevo cine latinoamericano en Viña del Mar. Santiago: Cesoc, 1990.

GARCÍA ESPINOSA, Julio. Por un cine imperfecto. In: Fundación Mexicana de Cineastas. Hojas de cine: testimonios y documentos del Nuevo Cine Latinoamericano. México D.F.: Universidad Autónoma Metropolitana, 1988 Volumen III.

GARCÍA MÁRQUEZ, Gabriel. La aventura de Miguel Littín clandestino en Chile. Bogotá: La Oveja Negra, 1986.

GAUTHIER, Guy. Le documentaire: un autre cinéma. Paris: Nathan, 1995.

GROSSER, Pierre. La guerre froide. Paris: Institut d'Études Politiques, 2007.

GUZMÁN, Patricio. Entrevista a Armando G. Tejeda. Revista Babab, número 13, maio de 2002. < http://www.babab.com/no13/patricio.htm>

HENNEBELLE, Guy. Os cinemas nacionais contra Hollywood. Rio de Janeiro: Paz e Terra, 1978.

HOBSBAWN, Eric. Era dos Extremos: O Breve Século XX. São Paulo: Companhia das Letras, 1995.

LETELIER, Jorge. ¿De qué hablamos cuando hablamos de cine chileno? La desmemoria obstinada. In: Mabuse Revista de Cine. Chile, abril de 2008. 
LITTÍN, Miguel. Cine chileno - la tierra prometida. Caracas: Rocinante, 1974.

LITTÍN, Miguel. Entrevista a Armando G. Tejeda. Revista Babab, número 0, janeiro de 2000. $<$ http://www.babab.com/no00/miguel littin.htm $>$

LITTIN, Miguel. Entrevista a Hans Erhmann em Cannes. In: Enfoque - Revista de Cine, número 4, Chile: verano-otoño, 1985.

MACAMBYRA, Marina. Manual de catalogação de filmes. São Paulo: ECA.

Manifiesto de los cineastas de la Unidad Popular.

MANNS, Patricio. Actas de Marusia. Santiago: Editorial Pluma y Pincel, 1993.

MARCORELLES, Louis. Une esthétique du réel, le cinéma direct. Unesco: 1963.

METZ, Christian. A significação no cinema. São Paulo: Perspectiva, 1977.

MILLÁN, Francisco Javier. Las huellas de Buñuel. La influencia de su obra cinematográfica en el cine latinoamericano. Madri: Teruel, 2002.

MONZANI, Josette. A lógica selvagem de Glauber. In Folhetim, suplemento da Folha de São Paulo, 13 de maio de 1984, pág. 11.

MONZANI, Josette. Gênese de Deus e o diabo na terra do sol. São Paulo: Annablume; Fapesp: Salvador: Fundação Gregório de Mattos/ Centro de Cultura Bahiana da UFBa, 2006.

MORIN, Edgar. Crônica de um filme. In: Encarte do DVD Chronique d'un été, lançado pela Vídeo Filmes, em 2008.

MOUESCA, Jacqueline. Cine Chileno: veinte años, 1970-1980. Santiago: Ministerio de Educación, 1992.

MOUESCA, Jacqueline. Cine y Memoria del siglo XX. Santiago: 1998.

MOUESCA, Jacqueline. Plano secuencia de la memoria de Chile: veinticinco años de cine chileno (1960-1980). Madrid: Ediciones del Litoral, 1988.

NAUGRETTE, Jean-Paul. Nous irons à Valparaiso. Paris: Critique 443, abril de 1984.

NúÑEZ, Fabián. O Nuevo Cine chileno - 1967-1973. Cinestesia Revista eletrônica de cinema, 2007.

NÚÑEZ, Fabián. Um olhar sobre o cinema chileno. In Revista Comunicação\&política, Volume 24, nº 1, Janeiro - Abril 2006.

OLAVE, D. e DE LA PARRA, M. Pantalla prohibida: la censura cinematográfica en Chile. Santiago: Grijalbo, 2001. 
OROZ, Silvia. Melodrama: o cinema de lágrimas da América Latina. Rio de Janeiro: Rio Fundo Editora, 1992.

OSSA COO, Carlos. Historia del cine chileno. Santiago: Quimantu, 1971.

PARANAgUÁ, Paulo Antonio. Cine documental en América Latina. Madrid: Ediciones Cátedra, 2003.

PARANAGUÁ, Paulo Antonio. Le cinéma brésilien. Paris: Centre G. Pompidou, 1987.

PARANAGUÁ, Paulo Antonio. O cinema na América Latina: longe de Deus e perto de Hollywood. Porto Alegre: L\&PM, 1985.

PARENTE, André. Narrativa e modernidade: os cinemas não-narrativos do pósguerra. Campinas: Papirus, 2000.

RAMOS, Fernão. Mas afinal... o que é documentário? São Paulo: Editora Senac, 2008 .

REZENDE, Luiz Augusto. Do direto a Moretti. In: RAMOS, Fernão; CATANI, Afrânio; MOURÃO, Maria Dora et GATTI, José (org). Estudos de cinema 2000 Socine. Porto Alegre: Sulina, 2001.

ROCHA, Glauber. Arraial, Cinema Novo e câmera na mão. In: Suplemento Dominical do Jornal do Brasil. Rio de Janeiro: 12 de agosto de 1961.

ROCHA, Glauber. Cartas ao Mundo (org: Ivana Bentes). São Paulo: Cia. das Letras, 1997.

ROCHA, Glauber. De cinestética. In: Ângulos, Salvador, número 13, julho de 1958 - págs. 115 a 127.

ROCHA, Glauber. Experiência Barravento: confissão sem moldura. In: Diário de Notícias de Salvador, 25-26 de dezembro de 1960.

ROCHA, Glauber. Revisão crítica do cinema brasileiro. São Paulo: Cosac \& Naify, 2003.

ROUCH, Jean. O cinema do futuro? In: Encarte do DVD Chronique d'un été, lançado pela Vídeo Filmes em 2008.

ROUQUIÈ, Alain. O extremo ocidente - introdução à América Latina. São Paulo: Editora Edusp, 1992.

SALES GOMES, Paulo Emílio. Cinema: Trajetória no Subdesenvolvimento. São Paulo: Paz e Terra, 1996. 
SALES GOMES, Paulo Emílio. Crítica de cinema no Suplemento Literário. Rio de Janeiro, 1981.

SANJINES, Jorge. Teoría y práctica de un cine junto al pueblo (1972). In: http://www.documentalistas.org.ar/notateoria.shtml?sh itm=81d54966d75bfcd6b847897a207c05ca

SANTANA, Alberto. Grandezas y miserias del cine chileno. Santiago: Editorial Misión, 1957.

SARNO, Geraldo. Glauber Rocha e o cinema Latino-Americano. Rio de Janeiro: Centro Interdisciplinar de Estudos Contemporâneos da Escola de Comunicação da UFRJ, 1995.

SCHUMANN, Peter B. Historia del cine latinoamericano. Trad. Oscar Zambrano. Buenos Aires: Legana, 1987.

SCHWARZ, Roberto. Cultura e política. São Paulo: Paz e Terra, 2001.

SILVEIRA, Walter da. A história do cinema vista da província. Salvador: Fundação Cultural do Estado da Bahia, 1978.

SILVEIRA, Walter da. Fronteiras do cinema. Rio de Janeiro: Tempo Brasileiro, 1966.

SOLANAS, Fernando E. e GETINO, Octavio. Cine, cultura y descolonización. Buenos Aires: Siglo XXI, 1973.

VEGA, Alicia. Re-visión del cine chileno. Santiago: Aconcagua/CENECA, 1979.

VIANY, Alex. O processo do Cinema Novo. Organização de José Carlos Avellar. Rio de Janeiro: Aeroplano, 1999.

VICENNOT, Emanuel. Malos tiempos: difusión y recepción del Nuevo Cine Latinoamericano en Francia. In: Miradas Revista del audiovisual, número 1. La Habana: enero de 2003.

XAVIER, Ismael. Alegorias do Subdesenvolvimento. Cinema Novo, Tropicalismo, Cinema Marginal. São Paulo: Brasiliense, 1993.

XAVIER, Ismael. O cinema brasileiro moderno. São Paulo: Paz e Terra, 2001.

XAVIER, Ismael. Sertão Mar: Glauber Rocha e a estética da fome. São Paulo: Cosac \& Naify, 2007. 


\section{Filmografia utilizada}

ASPILLAGA, Magdiel. Entrevista a Jorge Sanjinés. Cuba, 2004.

BIRRI, Fernando. Tire dié. Argentina, 1956-8.

CAHN, Guillermo. No nos trancarán el paso. Chile, 1971.

CAIOZZI, Silvio, PERELMAN, Pablo. A la sombra del sol. Chile, 1974.

CAPOVILA, Maurice. O Profeta da Fome. Brasil, 1970.

CASTILLA, Sergio. Mijita. Chile, 1970.

CASTILLA, Sergio. Prisioneros Desaparecidos. Chile-Cuba, 1979.

CÉSPEDES, Leonardo. Pintando con el pueblo. Chile.

CHASKEL, Pedro, RÍOS, Héctor. Venceremos. Chile, 1970.

CHASKEL, Pedro, SANZ, Luis Alberto. No es hora de llorar. Chile, 1971.

FLORES, Carlos, CAHN, Guillermo. Nutuayin Mapu (Recuperemos nuestra tierra). Chile, 1971.

FLORES, Carlos. Descomedidos y chascones. Chile, 1971-72.

GUZMÁN, Patricio. El Primer Año. Chile, 1971.

GUZMÁN, Patricio. La Batalla de Chile. Chile, 1973-79.

IVENS, Joris. ...A Valparaíso. Chile/França, 1962

IVENS, Joris. Le train de la victoire. Chile, 1964

LITTÍN, Miguel. Acta General de Chile. Chile-Cuba, 1986.

LITTÍN, Miguel. Actas de Marusia. Chile, 1975.

LITTÍN, Miguel. Compañero Presidente. Chile, 1971.

LITTÍN, Miguel. El Chacal de Nahueltoro. Chile, 1969.

LITTÍN, Miguel. La tierra prometida. Chile, 1974.

MALLET, María Luisa. Amuhuelai-Mi (Ya no te irás). Chile, 1971.

MARKER, Chris. Le fond de l'air est rouge. França, 1977.

MATELLART, Armand, MAYOUX, Valérie et Autres. La Spirale. França, 1976.

NORONHA, Linduarte. Aruanda. Brasil, 1960.

RÍOS, Héctor. Entre ponerle y no ponerle. Chile, 1972. 
ROCHA, Glauber. Amazonas, Amazonas. Brasil, 1966.

ROCHA, Glauber. Barravento. Brasil, 1961.

ROCHA, Glauber. Deus e o diabo na terra do sol. Brasil, 1964.

ROCHA, Glauber. História do Brasil. Cuba/Itália, 1974.

ROCHA, Glauber. Maranhão 66. Brasil, 1966.

ROCHA, Glauber. O dragão da maldade contra o santo guerreiro. Brasil, 1969.

ROCHA, Glauber. O Pátio. Brasil, 1959.

ROCHA, Glauber. Terra em Transe. Brasil, 1967.

SANJINÉS, Jorge. Yawar Mallku (Sangre de Cóndor). Bolivia, 1969.

SANZ, Luiz Alberto. Unos pocos caracoles. Chile, 1973.

SAPIAÍN, Claudio. Santa María de Iquique. Chile, 1971.

SOLANAS, Fernando. La Hora de los Hornos. Argentina, 1968. 


\section{ÍNDICE}

A

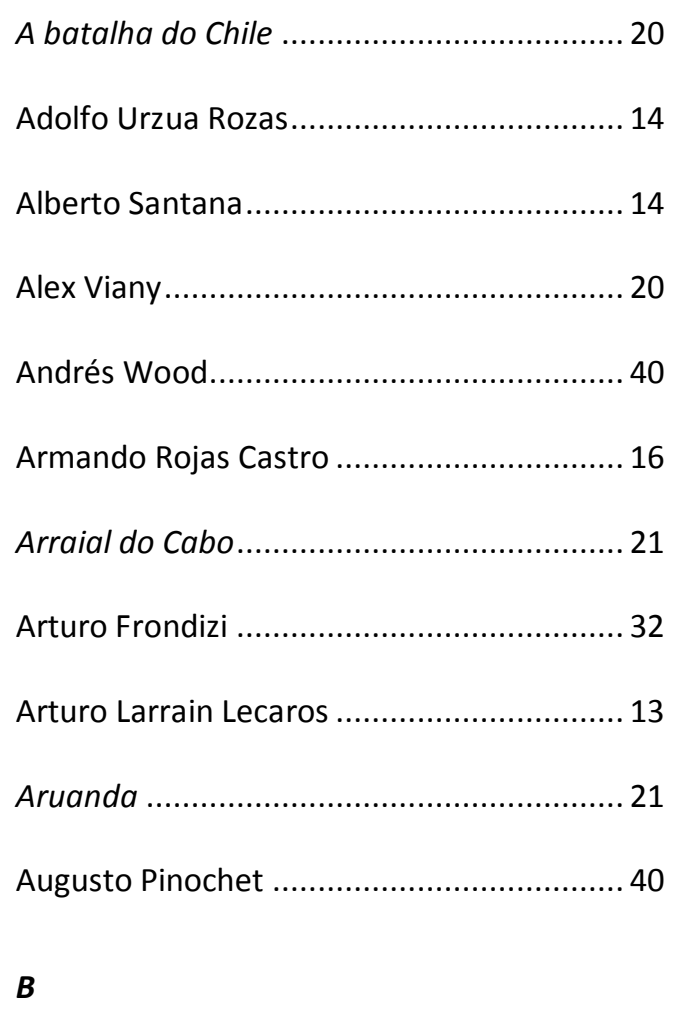

BRAVO, Sergio 15,17

C

Caliche Sangriento 21

Candid Eye 22

Carabineros de Chile 20

Carlos Flores . .35

Carlos Ossa 13,14

Carlos Pellegrini 14

Carlos Vattier .16

CASTRO, Armando Rojas. 16

Centre National de la Recherche Scientifique
Centro de Cine Experimental. 35

Centro Experimental de Cinematografía ..... 32

Centro Experimental de Cinematografía de

Roma

Ch

Charles Beachell ............................................ 22

CHENEVEY, Julio............................................ 13

Chile Films 17,35

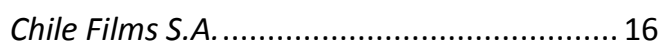

Chronique d'um Été ...................................26

Chronique d'un été ........................................23

Chronique d'un Été....................................... 28

C

Cimetieres dans la falaise 26

Cinema Direto $23,24,29$

Cinéma Verité 34,38

Cinéma Vérité $23,26,28,29,30$

Confesión al amanacer 17

CORFO 16,17

Crise $.23,25,26$

D

Dawson, Isla 10 40

Departamento de Cine de la CUT . 35

Departamento de Cine Experimental .... 15, 35

Diprocine 17,35 
E

Edgar Morin 23,28

Eduardo Frei 35

Eixo. 16

El husar de la muerte. 15

El ídolo 17

Elecciones 39

Enrique Vico 17

Escuela de Artes de la Comunicación 35

Escuela de Cine 35

Escuela Documental de Santa Fé 32

Escuela Oficial de Cinematografía de Madrid 35

Eugénio de Liguoro 15

$\boldsymbol{F}$

Fernando Birri $21,31,32,33$

Fernando Solanas 39

Festival de Cine Latinoamericano. 35

Festival de Cine Latinoamericano de Viña del

$$
\text { Mar. }
$$

Fiesta de los estudiantes. 14

Francisco Coloane. 16

Fraternité Nigérienne d'Abidjan 27

Frente Popular. 16
G

Gabriel García Márquez 33

Gabriel González Videla 17

GIAMBASTIANI, Salvador 14

Gilles Groulx 23

Glauber Rocha . 21

Grado 3. 40

Grande Guerra do Pacífico 21

Grierson. 22

Grito en el mar. 14

Groupe synchrone cinématographique léger

Guy Gauthier 23,30

GUZMÁN, Patrício. 20

H

Héctor Ríos 35,39

Helvio Soto 21

Henri Cartier-Bresson 20

Henri-Cartier Bresson

História del cine chileno

Hollywood $15,17,25,38$

Horacio Salinas 15

I

ICAIC. 33

Institut Français d'Afrique Noire 26 
Instituto de Cinematografia de la Universidad

de la República.

Instituto de Cinematografía de Santa Fé..... 32

Instituto de Cinematografía Educativa ........ 35

Instituto Fílmico 35

Inti Illimani

J

Jaguar 28

James Hood 25

Jean Lesage

Jean Rouch $23,28,34$

Jorge Délano 14,15

Jorge Müller 20

Jorge Sanjinés 20

José Bohr 15

José Román 35

Julio Chenevey. 13

Julio García Espinosa 33

Juro no volver a amar

\section{$L$}

La hora de los hornos. 39

Las chicas de la Avenida Pedro Montt

LECAROS, Arturo Larrain

Les maîtres fous 27

Ley de Defensa de la Democracia 17

Linduarte Noronha 21
LI

Llampo de sangre

\section{$L$}

Los funerales del Presidente Pedro Montt ... 13

Luis Emilio Recabarren............................... 14

Luis Moglia Barth ..................................... 16

Luis Pizarro ......................................... 14

Luiz Augusto Rezende ............................. 29

Luz y sombra........................................... 14

M

Machuca......................................................... 40

Manifiesto de los Cineastas de la Unidad

Popular ................................................ 36

Manuel Rodriguez................................. 14

Mário Carneiro ......................................... 21

Mario Handler ........................................... 39

Mario Ruspoli ........................................... 23

Michel Brault .................................... 22, 28

Miguel Littin ............................................ 36

Miguel Littín .................................... 21, 40

MIPE-TV .................................................. 23

Moi, um noir .............................................. 26

Moi, un Noir.............................................. 27

Momento decisivo ............................ 19, 20

Musée de l'Homme...................................... 26 
N

Nelson Pereira dos Santos 20

Neo-realismo

$20,33,38$

Norte y Sur. 15

Nouvella Vague 38

Nuevo Cine Latinoamericano11, 20, 32, 34, 38

0

O Chacal de Nahueltoro 36

Octávio Getino. 39

Office National du Film

OSSA, Carlos 13,14

$\boldsymbol{P}$

Partido Comunista 17

Patrício Guzmán 20,35

Paulo Cesar Saraceni 21

Paulo Emílio 11

Pedro Aguirre Cerda 16

Pedro Chaskel 35,39

Pedro Sienna 14,15

PELLEGRINI, Carlos 14

Pierre Chenal 17

PIZARRO, Luis 14

Pour un Nouveau Cinéma-Vérite 28

Primaires 23

Primárias 26

\section{$\boldsymbol{R}$}

Rafael Sanchez........................................ 17

Rafael Sánchez........................................ 35

Raoul Ruiz ............................................. 36

Recuerdos del mineral El Teniente............... 14

Revolução Cubana .................................... 31

Richard Leacock ..................................... 23

Robert Drew ................................... 24, 26

Roberto Artiagoitía .................................. 40

Robinson ............................................... 26

Romance de medio siglo .......................... 16

ROZAS, Adolfo Urzua ............................... 14

$S$

Salvador Allende ........................................ 36

Salvador Giambastiani ............................... 14

Santiago antiguo ..................................... 14

Seminário Robert Flaherty ................. 22, 23

Sergio Bravo ..............................15, 17, 35

Sergio Castilla ........................................... 35

Service d'Information de la Côte d'Ivoire .... 27

SIENNA, Pedro 14,15

$T$

Tanquetazo............................................... 20

Teatro Experimental ............................... 16

Tire dié..................................................... 32

Tomás Gutiérrez Alea ............................... 33 
Três tristes tigres

$\boldsymbol{U}$

Ugo Ulive

39

Unidad Popular

11,35

Universidad de Chile

$15,16,35$

Universidad de la República.
Universidad del Litoral 32

Universidade Federal da Paraíba

Université de Californie à Los Angeles...

\section{$\boldsymbol{V}$}

Venceremos................................................. 39

Vivian Malone ............................................ 25 


\section{Contatos}

Correio-e:

nico.rodrigues@usp.br

nico.rodrigues@gmail.com

Fones:

0xx11 - 2925-6831

0xx11-8614-8738 
ANEXO 1 - Ficha técnica dos filmes utilizados 


\section{El Primer Año}

Título original: El Primer Año

Titulo em português: O primeiro ano

Titulo em francês: La première année

Direção: GUZMÁN, Patricio (1941-)

País e data: Chile, 1971

Idiomas: espanhol

Legenda: português

Duração: 90 minutos

Resumo: avaliação do primeiro ano de governo da Unidad Popular

Assunto: Unidad Popular; governo; Chile

Forma: Filme

Escola: Cine de La Unidad Popular 
La batalla de Chile: La lucha de un pueblo sin armas - Primera parte: La insurreción de la burguesía

Título original: La batalla de Chile: La lucha de un pueblo sin armas - Primera parte:

La insurreción de la burguesía

Titulo em português: A batalha do Chile - Parte I: a insurreição da burguesia

Titulo em francês: La bataille du Chili (1ère partie): L'insurection de la Burgesia

Direção: GUZMÁN, Patricio

País e data: Chile/Venezuela/Cuba/França, 1975

Idiomas: espanhol

Legenda: português

Duração: 106 minutos

Produção: Equipo Tercer Año; Instituto Cubano de Arte e Industria

Cinematográfica, Chris MARKER

Produção executiva: ELTON, Federico

Roteiro: BARTOLOME, Jose; CHASKEL, Pedro; ELTON, Federico; ESPINOSA, Julio García; GUZMÁN, Patricio

Assistente de direção: PINO, José

Fotografia: MÜLLER, Jorge

Montagem: CHASKEL, Pedro

Som: MENZ, Bernardo

Assunto: golpe de estado; Chile; Salvador Allende; América Latina

Forma: Filme

Escola: Nuevo cine latinoamericano / Cine de La Unidad Popular 
La batalla de Chile: La lucha de un pueblo sin armas - Segunda parte: El golpe de estado

Título original: La batalla de Chile: La lucha de un pueblo sin armas - Segunda parte: El golpe de estado

Titulo em português: A batalha do Chile - Parte I: O golpe de estado

Titulo em francês: La bataille du Chili (2ème partie): Le coup d'éta

Direção: GUZMÁN, Patricio

País e data: Chile/Cuba/França, 1976

Idiomas: espanhol

Legenda: português

Duração: 99 minutos

Produção: Equipo Tercer Año; Instituto Cubano de Arte e Industria

Cinematográfica, Chris Marker

Produção executiva: MARKER, Chris

Roteiro: BARTOLOME, Jose; CHASKEL, Pedro; ELTON, Federico; ESPINOSA, Julio García; GUZMÁN, Patricio

Assistente de direção: PINO, José

Fotografia: MÜLLER, Jorge

Montagem: CHASKEL, Pedro

Som: MENZ, Bernardo

Assunto: golpe de estado; Chile; Salvador Allende; América Latina

Forma: Filme

Escola: Nuevo cine latinoamericano / Cine de La Unidad Popular 
La batalla de Chile: La lucha de un pueblo sin armas - Tercera parte: El poder popular

Título original: La batalla de Chile: La lucha de un pueblo sin armas - Tercera parte:

El poder popular

Titulo em português: A batalha do Chile - Parte III: O poder popular

Titulo em francês: La bataille du Chili (3ème partie)

Direção: GUZMÁN, Patricio

País e data: Chile/Cuba/Venezuela, 1978

Idiomas: espanhol

Legenda: português

Duração: 90 minutos

Produção: Equipo Tercer Año; Instituto Cubano de Arte e Industria

Cinematográfica, Chris Marker

Produção executiva: MARKER, Chris

Roteiro: BARTOLOME, Jose; CHASKEL, Pedro; ELTON, Federico; ESPINOSA, Julio García; GUZMÁN, Patricio

Assistente de direção: PINO, José

Fotografia: MÜLLER, Jorge

Montagem: CHASKEL, Pedro

Som: MENZ, Bernardo

Assunto: golpe de estado; Chile; Salvador Allende; América Latina

Forma: Filme

Escola: Nuevo cine latinoamericano / Cine de La Unidad Popular 


\section{Actas de Marusia}

Título original: Actas de Marusia

Titulo em português: Atas de Marusia

Titulo em francês: Actes de Marusia

Direção: LITTÍN, Miguel

País e data: México, 1975

Idiomas: espanhol

Legenda: português

Duração: 110 minutos

Produção: Conacine, FELIU, Arturo

Produção executiva: BADIN, Anuar

Roteiro: LITTIN, Miguel

Assistente de direção: LLORCA, Mario; OLIVO, Valerio; SÁNCHEZ, Jorge

Baseado da obra de: MANNS, Patricio

Adaptação: TAVERNA G., Freddy

Fotografia: STAHL JR., Jorge

Diretor de Arte: YTUARTE, Agustín

Diretor de Set: SERRANO, Raúl

Montagem: AUPART, Ramón; VALENZUELA, Alberto

Som: CARLES, José B., CRUZ, Abraham (editor); GAVIRA, Gonzalo (efeitos);

PORTILLO, Reynaldo P. (operador de boom)

Cenários: SERRANO, Raúl

Música: THEODORAKIS, Mikis

Efeitos especiais: FALOMIR, Raul

Intérpretes: Armando Acosta; Arturo Beristáin; Diana Bracho; José B. Carles; Patricio Castillo; Alicia del Soto; Jorge Fegán; Guillermo Gil; Salvador Godínez; Ernesto Gómez Cruz; Federico González; Manuel 'Flaco' Ibáñez; Max Kerlow; 
Mariana Lobo; Eduardo López Rojas; Margarito Luna; Silvia Mariscal; Francisco Morayta; Arthur Nations; Claudio Obregón; Alejandro Parodi; Julián Pastor; Rodrigo Puebla; Ramiro Ramírez; Gabriel Retes; Patricia Reyes Spíndola; Ibet Reyna; José Carlos Ruiz; Salvador Sánchez; Jorge Santoyo; Magdalena Solorzano; Domingo Soto; Gian Maria Volonté

Forma: Filme

Escola: Nuevo cine latinoamericano 


\section{Compañero Presidente}

Título original: Compañero Presidente

Direção: LITTÍN, Miguel (1942-)

País e data: Chile, 1971

Idiomas: espanhol

Legenda: português

Duração: 15 minutos (?)

Produção: Chile Films

Forma: Filme

Escola: Nuevo cine latinoamericano / Cine de La Unidad Popular 


\section{El Chacal de Nahueltoro}

Título original: El Chacal de Nahueltoro

Titulo em português: $\mathrm{O}$ chacal de Nahueltoro

Direção: LITTÍN, Miguel

País e data: Chile/México, 1969

Idiomas: espanhol

Legenda: português

Duração: 88 minutos

Produção: Cine Experimental de la Universidad de Chile, Cinematografia Tercer Mundo

Roteiro: Miguel LITTIN

Fotografia: Hector RIOS

Montagem: Pedro CHASKEL

Música: Sergio ORTEGA

Intérpretes: Nelson VILLAGRA; Shenda ROMÁN; Luis MELO; Ruben SOTOCONIL; Armando FENOGLIO; Marcelo ROMO; Luis ALARCON; Hector NOGUERA; Pedro VILLAGRA; Roberto NAVARRETE; Rafael BENAVENT

Assunto: polícia; justiça, execução, pena de morte, família, política, infanticídio Forma: Filme

Escola: Nuevo cine latinoamericano / Cine de La Unidad Popular 


\section{La tierra prometida}

Título original: La tierra prometida.

Titulo em português: A terra prometida

Direção: LITTÍN, Miguel

País e data: Chile/Cuba, 1974

Idiomas: espanhol

Legenda: português

Duração: 120 minutos

Produção: Cinematografia Tercer Mundo, Instituto Cubano de Arte e Indústria

Intérpretes: Nelson VILLAGRA; Marcelo GAETE; Rafael BENAVENTE; Mireya KULCHEWSKY; Anibal REYNA; Carmen BUONO

Forma: Filme

Escola: Nuevo cine latinoamericano 


\section{Amazonas, Amazonas}

Título original: Amazonas, Amazonas

Titulo em francês: Amazonas, Amazonas

Direção: ROCHA, Glauber (1939-1981)

País e data: Brasil, 1966

Idiomas: português

Duração: 15 minutos

Produção: Departamento de Turismo e Promoções do Estado do Amazonas MENDES, Luiz Augusto

Assistente de Produção: ROSAS, Edmilson

Roteiro: ROCHA, Glauber

Assistente de Direção: AZEVEDO, Rubens de

Fotografia: DUARTE, Fernando

Som: BARROZO NETO, Helio

Música: VILLA-LOBOS, Heitor

Forma: Filme

Escola: Cinema nôvo 


\section{Barravento}

Título original: Barravento

Titulo em francês: Barravento

Direção: ROCHA, Glauber (1939-1981)

País e data: Brasil, 1961

Idiomas: português

Duração: 80 minutos

Produção: Iglu Filmes; SCHINDLER, Rex, NETO, Braga

Produtor associado: SINGE, David

Diretor de produção: MAGALHÃES, José Telles de

Produção executiva: PIRES, Roberto

Roteiro: ROCHA, Glauber; MAGALHÃES, José Telles de

Assistentes de direção: GUIMARÃES, Álvaro, LIMA, Waldemar

Diálogos: ROCHA, Glauber, SANTOS, Luiz Paulino dos

Baseado da obra de: SANTOS, Luiz Paulino dos (Idéia Original)

Fotografia: RABATONY, Tony; LIMA, Waldemar

Montagem: SANTOS, Nelson Pereira dos

Som: BARROZO NETO, Helio; JOSÉ, Geraldo; SANTANA, Oscar

Figurinos: ROCHA, Lúcia

Música: BRUNO, Washington (Canjiquinha): samba de roda e capoeira; Batatinha: samba

Intérpretes: Antônio Sampaio (Pitanga) - Firmino; Luiza Maranhão - Cota, Lucy Carvalho - Naína, Aldo Teixeira - Aruã, Lídio Cirillo dos Santos (Lídio Silva) Mestre; Rosalvo Plínio, Alair Liguori, Antonio Carlos dos Santos, D. Zezé, Flora Vasconcelos, Jota Luna, Hélio Moreno Lima, Francisco dos Santos Brito; participação especial em candomblés: D. Hilda; samba de roda e capoeira: D. Zezé, Adinora, Arnon,Sabá;orient.de candomblés: Hélio de Oliveira.

Locações: Praia do Buraquinho, Itapoã Flamengo (Salvador,BA)

Escola: Cinema novo 


\section{Deus e o diabo na terra do sol}

Título original: Deus e o diabo na terra do sol

Titulo em espanhol: Dios y el diablo en la tierra del sol

Titulo em francês: Le dieu noir et le diable blond

Direção: ROCHA, Glauber (1939-1981)

País e data: Brasil, 1964

Idiomas: português

Duração: 110 minutos

Produção: Copacabana Filmes; MENDES, Luiz Augusto

Produtor Associado: BARBOSA, Jarbas; ROCHA, Glauber

Produção executiva: AZEVEDO, Agnaldo

Roteiro: ROCHA, Glauber, LIMA Jr.,Walter

Diálogos: ROCHA, Glauber, SOARES, Paulo Gil

Assistente de Direção: SOARES, Paulo Gil; LIMA Jr, Walter

Fotografia: LIMA, Waldemar

Montagem: VALVERDE, Rafael

Letreiros: Lygia Pape

Gravuras: Calasans Neto

Cartaz: Rogério Duarte

Corte de negativos: ERITA, Lucia

Direção de arte: SOARES, Paulo Gil

Som: VIANA, Aluizio; JOSÉ, Geraldo (efeitos); AZEVEDO, Agnaldo

Canções: Sérgio Ricardo (melodia), Glauber Rocha (letra)

Violão e voz: Sérgio Ricardo

Continuidade: Walter Lima Jr

Figurinos: SOARES, Paulo Gil

Cenários: SOARES, Paulo Gil

Música: VILLA-LOBOS, Heitor; RICARDO, Sergio 
Intérpretes: Geraldo del REY; Yona MAGALHÃES; Othon BASTOS; Maurício do VALLE; Lidio SILVA; Sonia dos HUMILDES; João GAMA; Antônio PINTO; Milton RODA; ROQUE; moradores de Monte Santo

Locações: Monte Santo, Feira de Santana, Salvador, Canché (Cocorobó), Canudos (BA)

Forma: Filme

Escola: Cinema nôvo 
Maranhão 66

Título original: Maranhão 66

Titulo em espanhol:

Direção: ROCHA, Glauber

País e data: Brasil, 1966

Idiomas: português

Duração: 11 minutos

Produção: Mapa Filmes; Luiz Carlos Barreto; Zelito Viana

Diretor de Produção: Zelito Viana

Fotografia: Fernando Duarte

Montagem: João Ramiro Melo

Som Direto: Eduardo Escorel

Forma: Filme

Escola: Cinema nôvo 


\section{O dragão da maldade contra o santo guerreiro}

Título original: O dragão da maldade contra o santo guerreiro

Titulo em francês: Antonio das Mortes

Direção: ROCHA, Glauber

País e data: Brasil, 1969

Idiomas: português

Legenda: português

Duração: 95

Produção: Mapa Filmes; Glauber Rocha, Zelito Viana, Luiz Carlos Barreto, Claude Antoine

Diretores de produção: Demerval Novais de Carvalho, Agnaldo Azevedo

Produção executiva: Zelito Viana

Administrador: Tácito Val Quintas

Roteiro: ROCHA, Glauber

Assistentes de direção: Antônio Calmon, Ronaldo Duarte

Fotografia: Afonso Beato

Câmera: Ricardo Stein

Assistente de câmera: André Faria

Maquinistas: Pintinho, Eutímio, Daniel

Eletricistas: Roque Araújo, Chiquinho, Messias

Trajes de Odete Lara: Hélio Eichbauer

Letreiros: Roberto Lunari

Cartaz: Jânio de Freitas

Locação: Milagres (BA)

Laboratório de imagem: Rex Filmes

Estúdio de som: Rivaton

Montagem: Eduardo Escorel

Assistente de montagem: Amauri Alves

Som: 
Som direto: Walter Goulart

Operador de microfone: Diego Arruda

Mixagem: Carlos della Riva

Efeitos sonoros: Paulo Lima

Figurinos: Glauber Rocha, Paulo Lima, Paulo Gil Soares

Cenários: Glauber Rocha

Assistentes de cenografia: Paulo Lima, Paulo Gil Soares

Música: Unkrimakrimkrim, Ritmetrom (Marlos Nobre); Coirana (Walter Queirós);

Antonio das Mortes (Sérgio Ricardo); Macumba de Milagres (Anônimo); Chegada

de Lampião no Inferno (Cego de Feira)

Intérpretes: Maurício do Valle; Odete Lara; Othon Bastos; Hugo Carvana; Jofre Soares; Lorival Pariz; Rosa Maria Penna; Emanuel Cavalcant; Mário Gusmão;

Vinícius Salvatori; Sante Scaldaferri

Forma: Filme

Escola: Cinema nôvo 
O Pátio

Título original: O Pátio

Titulo em espanhol:

Direção: ROCHA, Glauber

País e data: Brasil, 1959

Idiomas: português

Legenda: português

Duração: 11 minutos

Roteiro: Glauber Rocha

Fotografia: José Ribamar de Almeida; Luiz Paulino dos Santos

Montagem: Souza Jr.

Música: Concreta (tema central: "Sinfonia para um Homem Só" de Pierre Henry e Pierre Schaeffer)

Intérpretes: Helena Ignez e Solon Barreto

Locações: Salvador (Ba)

Forma: Filme

Escola: Cinema nôvo 


\section{Terra em Transe}

Título original: Terra em Transe

Titulo em espanhol: Terra en Transe

Titulo em francês: Terre en transe

Direção: ROCHA, Glauber

País e data: Brasil, 1967

Idiomas: português

Duração: 115 minutos

Produção: Mapa Filmes e Difilm

Produção executiva: Zelito VIANA

Produtores associados: Luiz Carlos Barreto; Carlos Diegues; Raymundo

WANDERLEY; Glauber ROCHA

Gerente administrativo: Tácito AL QUINTAS

Roteiro: Glauber Rocha

Assistentes de direção: Antônio CALMON, Moisés KENDLER

Fotografia: Luiz Carlos BARRETO

Câmara: LUFTI, Dib

Assistente de câmara: José VENTURA

Fotógrafos de cena: Luiz Carlos BARRETO, Lauro ESCOREL FILHO

Trabalhos fotográficos: José MEDEIROS

Eletricistas: Sandoval Dória; Vitaliano MURATORI

Montagem: Eduardo ESCOREL

Assistente de montagem: Mair TAVARES

Montadora de negativo: Paula CRACEL

Engenheiro de som: Aluizio Viana

Figurinos: Paulo GIL SOARES

Cenários: Paulo GIL SOARES 
Música: Carlos GOMES (O Guarani), Villa-Lobos (Bachianas n.3 e 6), Verdi (abertura de Othelo); canto negro Aluê do candomblé da Bahia, samba de favela do Rio

Música original: Sérgio RICARDO

Regente: Carlos Monteiro DE SOUSA

Quarteto: Edson MACHADO

Vozes: Maria da GRAÇA (Gal COSTA) e Sérgio RICARDO

Trajes de Danuza Leão: Guilherme GUIMARÃES

Letreiros: Mair TAVARES

Carta: Luiz Carlos RIPPER

Intérpretes: Jardel Filho - PauloMartins; Paulo Autran - D. Porfírio Diaz; José Lewgoy - D. Filipe Vieira; Glauce Rocha - Sara; Paulo Gracindo - D. Júlio Fuentes; Hugo Carvana - Álvaro; Danuza Leão - Sílvia; Jofre Soares - Padre Gil; Modesto de Sousa - senador; Mário Lago - secretário de segurança; Flávio Migliaccio - homem do povo; Telma Reston - mulher do povo; José Marinho - Jerônimo; Francisco Milani - Aldo; Paulo César Pereio - estudante; Emanuel Cavalcanti - Felício; Zózimo Bulbul - Repórter; Antonio Câmera- índio; Echio Reis, Maurício do Valle, Rafael de Carvalho, Ivan de Souza

Locações: Rio de Janeiro e Duque de Caxias (RJ)

Laboratório de imagem: Líder Cine Laboratórios

Estúdio de som: Herbert Richers

Forma: Filme

Escola: Cinema nôvo 


\section{Venceremos}

Título original: Venceremos

Titulo em português: Venceremos

Direção: CHASKEL, Pedro e RÍOS, Héctor

País e data: Chile, 1970

Formato da tela: $4: 3$

Idiomas: espanhol

Legenda: português

Duração: 16 minutos

Produção: Departamento de Cine Experimental da UChile

Câmara: CARVAJAL, Samuel

Som: CESPEDES, Leonardo

Música: Santiago e Quisiera volverme noche (PARRA, Angel); Dame la mano

(MISTRAL, Gabriele); Un gallo de amanecida (REYES, Alejandro); Elegia

(CARRASCO, Eduardo)

Forma: Filme

Escola: Cinema de La Unidad Popular 


\section{Tire dié}

Título original: Tire dié

Titulo em português: Tire dié

Titulo em francês: Tire dié

Direção: BIRRI, Fernando

País e data: Argentina, 1960

Idiomas: espanhol

Duração: 33 minutos

Roteiro: BIRRI, Fernando

Fotografia: BIRRI, Fernando

Montagem: RIPOLL, Antonio

Som: FEZIA, Mario

Intérpretes: PETRONE, Francisco; GALLO, María Rosa; LURO, Guillermo Cervantes; população de Santa Fé

Locações: Santa Fé

Forma: Filme

Escola: 


\section{...A Valparaíso}

Título original: ...A Valparaíso

Titulo em português: Á Valparaíso

Titulo em francês: ...A Valparaíso

Direção: IVENS, Joris

País e data: Chile/França, 1962

Idiomas: francês

Legenda: português

Duração: 37 minutos

Produção: Argos-Films, Cine Experimental de la Universidad de Chile

Produção executiva: DAUMAN, Anatole; LIFCHITZ, Philippe

Assistentes de Produtores: CORNEJO, Luis; BRAVO, ALTEZ, Sergio; Augustin;

YANEZ, Rebecca; OLALLA, Joaquin; BÖKER, Carlos

Narrator: PIGAUT, Roger

Roteiro: IVENS, Joris

Fotografia: STROUVÉ, Georges

Assistente de fotografia: GUZMÁN, Patricio; MARTINEZ, Leonardo

Montagem: RAVEL, Jean

Comentário: MARKER, Chris

Música: BECERRA, Gustavo

Música original: DELERUE, Georges

Forma: Filme 
ANEXO 2 - Manifestos 


\section{Manifiesto de los Cineastas de la Unidad Popular}

"Cineastas chilenos: es el momento de emprender juntos con nuestro pueblo, la gran tarea de liberación nacional y de la construcción del socialismo.

Es el momento de comenzar a rescatar nuestros propios valores como identidad cultural y política.

Basta ya de dejarnos arrebatar por las clases dominantes, los símbolos que ha generado el pueblo en su larga lucha por la liberación.

Basta ya de permitir la utilización de los valores nacionales como elemento de sustentación del régimen capitalista.

Partamos del instinto de clase del pueblo y contribuyamos a que se convierta en sentido de clase.

No a superar las contradicciones sino a desarrollarlas para encontrar el camino de la construcción de una cultura lúcida y liberadora.

La larga lucha de nuestro pueblo por la emancipación, nos señala el camino.

A retomar la huella perdida de las grandes luchas populares, aquella tergiversada por la historia oficial, y devolverla al pueblo como su herencia legítima y necesaria para enfrentar el presente y proyectar el futuro.

A rescatar la figura formidable de Balmaceda, antioligarca y antiimperialista.

Reafirmemos que Recabarren es nuestro y del pueblo. Que Carrera, O’Higgins, Manuel Rodríguez, Bilbao y que el minero anónimo que cayó una mañana o el campesino que murió sin haber entendido el por qué de su vida ni de su muerte, son los cimientos fundamentales de donde emergemos.

Que la bandera chilena es bandera de lucha y de liberación, patrimonio del pueblo, herencia suya.

Contra una cultura anémica y neocolonizada, pasto de consumo de una élite pequeño burguesa decadente y estéril, levantemos nuestra voluntad de construir juntos e inmersos en el pueblo, una cultura auténticamente NACIONAL y por consiguiente, REVOLUCIONARIA.

Por lo tanto, declaramos: 
1. Que antes de cineastas, somos hombres comprometidos con el fenómeno político y social de nuestro pueblo y con su gran tarea: la construcción del socialismo.

2. Que el cine es un arte.

3. Que el cine chileno, por imperativo histórico, deberá ser un arte revolucionario.

4. Que entendemos por arte revolucionario aquel que nace de la realización conjunta del artista y del pueblo unidos por un objetivo común: la liberación. Uno, el pueblo, como motivador de la acción y en definitiva el creador, y el otro, el cineasta, como su instrumento de comunicación.

5. Que el cine revolucionario no se impone por decreto. Por lo tanto, no postulamos una forma de hacer cine sino tantas como sean necesarias en el transcurrir de la lucha.

6. Que, no obstante, pensamos que un cine alejado de las grandes masas se convierte fatalmente en un producto de consumo de la élite pequeño burguesa que es incapaz de ser motor de la historia.

El cineasta, en este caso, verá su obra políticamente anulada.

7. Que rechazamos todo sectarismo en cuanto a la aplicación mecánica de los principios antes enunciados, o a la imposición de criterios formales oficiales en el quehacer cinematográfico.

8. Que sostenemos que las formas de producción tradicionales son un muro de contención para los jóvenes cineastas y en definitiva implican una clara dependencia cultural, ya que dichas técnicas provienen de estéticas extrañas a la idiosincrasia de nuestros pueblos.

9. Que sostenemos que un cine con estos objetivos implica necesariamente una evaluación crítica distinta, afirmamos que el gran critico de un film revolucionario es el pueblo al cual va dirigido, quien no necesita "mediadores que lo defiendan y lo interpreten".

10. Que no existen filmes revolucionarios en sí. Que éstos adquieren categoría de tales en el contacto de la obra con su público y principalmente en su repercusión como agente activador de una acción revolucionaria. 
11. Que el cine es un derecho del pueblo y como tal deberán buscarse las formas apropiadas para que éste llegue a todos los chilenos.

12. Que los medios de producción deberán estar al alcance por igual de todos los trabajadores del cine y que en este sentido no existen derechos adquiridos sino que, por el contrario, en el gobierno popular, la expresión no será un privilegio de unos pocos, sino el derecho irrenunciable de un pueblo que ha emprendido el camino de su definitiva independencia.

13. Que un pueblo que tiene cultura es un pueblo que lucha, resiste y se libera.

CINEASTAS CHILENOS, VENCEREMOS. 


\section{Teoría y práctica de un cine junto al pueblo}

Jorge Sanjines (1972)

\section{LA EXPERIENCIA BOLIVIANA}

El cine boliviano nace y se desarrolla siguiendo dos caminos diferentes y contrapuestos: el uno junto al pueblo y el otro contra el pueblo. Estos dos caminos que pueden tipificar toda la historia política de Bolivia, en la que permanentemente la pugna de los intereses nacionales y antinacionales define y determina su destino, son también los pasos abiertos y elegibles por los que se orientan las corrientes del arte en ese país.

En 1929 se filma el primer largometraje mudo en Bolivia. Se llamaba Wara Wara, y trataba sobre una leyenda de los incas. Le suceden otros pocos intentos de cine argumentado y muchos documentales mudos que se procesaban allí mismo. Cuando el sonido llega y se incorpora al cine, la actividad desaparece, pues la técnica se complica y los equipos y medios que se requieren son muy costosos.

Pasan prácticamente veinte años de silencio en el cine boliviano, y sólo en 1950 un pequeño grupo de pioneros encabezados por Jorge Ruiz realiza la primera película sonora boliviana de carácter documental. Son ellos los que trabajan, muchos años, en medio de grandes dificultades, realizando valiosos documentales no exentos de belleza y calidad técnica. En especial uno de ellos es extraordinario y obtiene el primer premio en el festival de cine organizado por el Sodre de Uruguay en 1956. Se flama Vuelve Sebastiana; esta filmado en colores y trata sobre la vida y vicisitudes de un antiguo grupo indígena del Altiplano: los indios Chipayas.

Mas tarde filman lo que podría considerarse como la primera película de largometraje sonora boliviana La vertiente. Se filmo en $35 \mathrm{~mm}$, con sonido directo, y en ella trabajaron todos los cineastas bolivianos. Era el año 1958. La película tenía muchos valores, en especial aquellas partes que tenían carácter documental, confirmando así las notables dotes de documentalista de Ruiz. Fallaban la interpretación y la estructura interna. Pero fue un logro importante, aunque no fue reconocido suficientemente. 
Actualmente el grupo de Ruiz sigue produciendo documentales y ha realizado uno que otro film de largometraje de características comerciales. Con la separación de Oscar Soria nace un nuevo equipo de cineastas, el Grupo Ukamau, que en aquel entonces aun no llevaba ese nombre, pues lo adoptó sólo mas tarde del titulo de su primer largometraje. Cabe hacer notar que en 1961 el cine revolucionado no existe en América Latina; que Bolivia vive un aislamiento cultural muy grande y que solamente el impacto de la tremenda injusticia social circundante pudo despegar una actitud de solidaridad por los problemas de las mayorías en ese grupo nuevo de cineastas que provenía de la burguesía nacional. Es difícil establecer en que momento los hombres se deciden por la revolución. Es un proceso. Sin embargo en Bolivia la muerte y la miseria golpean los ojos y los oídos minuto a minuto, y los hombres inquietos que lanzan una pregunta reciben a gritos la respuesta. Poco a poco se estructuró la idea del papel que debería jugar un cine nacional en un país pobre. Los objetivos no fueron tan precisos como lo son hoy, y fueron recortándose de la propia experiencia respecto de la realidad objetiva; resultaron necesariamente ligados al interés de las mayorías desposeídas y se establecieron como metas de lo que se entendió como la responsabilidad del artista, del intelectual, que debía, en buena parte, su propia condición de privilegiado al desgaste, al hambre, al exterminio de esas mayorías. El proceso y convulsión social que desencadenó la revolución de 1952 tuvo mucho que ver con la toma de conciencia de los cineastas comprometidos, como se vera mas adelante.

De esa conciencia, que se convierte en compromiso con la causa del pueblo, nace una actitud militante en estos cineastas que se deciden a hacer un cine comprometido, político, urgente y combatiente. Este cine nacional, ávido de poner el dedo en la llaga, no gusta, por supuesto, a los críticos ni intelectuales conservadores del statu quo, del atraso y del sometimiento cultural y económico. Para ellos, las películas del Grupo Ukamau son panfletos extremistas, sin ninguna importancia artística; las menosprecian e ignoran. Algunos matutinos, como El Diario de La Paz, no mencionan jamas a este cine. El directorio del periódico prohibe a sus redactores mencionar los nombres de los cineastas del Grupo Ukamau y los cables, que a veces llegan del exterior trayendo novedades sobre algún premio o comentados, son archivados. Pero importa poco. Ya no se toman como orientación, como palabra 
santa, la critica ni la información reaccionarias. Ya no se cree mas en la predica de la clase dominante colonizada culturalmente, que desprecia los movimientos progresistas en el arte y que exalta el arte por el arte, que propugna la búsqueda y la definición del ser metafísico en un país en el que no se sabe definir al ser físico, la realidad objetiva.

Se comprende que todo este afán de menospreciar el interés de los intelectuales y artistas por la problemática nacional tiene como inspirador al imperialismo, que busca la apatía y el desinterés de los bolivianos por sus propios problemas, que financia revistas y organismos culturales que intentan agrupar a jóvenes valores nacionales en tomo al culto por lo universal y la problemática metafísica. Toda expresión artística que se identifica con el país y toca problemas sociales es tildada de política y se crea en torno a este concepto la acepción peyorativa que opera de espantapájaros sobre muchos jóvenes poetas, escritores, pintores. Sin embargo, otros se dan cuenta y se sindicalizan porque saben que el tiempo es corto y los medios escasos para combatir la poderosa maquinaria de seducción cultural y explotación económica que ha instalado el imperialismo, y al que sirve tan perfectamente bien la ciase dominante.

Ahora se hace necesario considerar el paso de este cine revolucionado de la defensa a la ofensa. El cine quejumbroso, llorón y paternal del comienzo pasó a ser un cine ofensivo, combatiente y capaz de asestar golpes contundentes al enemigo. ¿Como ocurrió esto?

Las primeras películas del Grupo Ukamau mostraban el estado de pobreza y miseria de algunas capas de la población. Estas películas, consideradas primero muy útiles, se limitaban en el fondo a recordar a mucha gente de las ciudades, a las capas medias, a la burguesía y pequeña burguesía que asistía a los teatros donde se pasaban que existía otra gente, con la que se convivía en la misma ciudad o que vivía en las minas y en el campo, que se debatía en una deplorable miseria, callada y estoicamente. Pero fueron las proyecciones populares, las proyecciones en las minas o barrios marginales las que les abrieron los ojos a esos jóvenes cineastas y los ubicaron correctamente. Fue allí que descubrieron que ese cine era incompleto, insuficiente, limitado; que además de los defectos técnicos contenía defectos de concepción, defectos de contenido. Fue la misma gente del pueblo la que les hizo 
notar esos defectos, cuando les dijeron que ellos conocían casos mas terribles de pobreza y sufrimiento que los que los cineastas les mostraban; en otras palabras: con ese tipo de cine no se les daba a conocer nada nuevo. Los cineastas revolucionarios pensaron entonces que andaban por mal camino, que el pueblo no tenia interés en conocer este cine que nada le aportaba, aparte de satisfacer la curiosidad de verse reflejado en la pantalla. Se dieron cuenta de que la miseria era mejor conocida por el pueblo que por los cineastas que intentaban mostrarla, puesto que esos obreros, esos mineros, esos campesinos, eran y son en Bolivia los protagonistas de la miseria, que por lo tanto aparte de sentimentalizar a unos cuantos burgueses individualistas, ese cine no servía para nada.

Entonces surgió la pregunta: ¿que es lo que le interesa conocer al pueblo, puesto que es al pueblo a quien hay que dirigirse?

La respuesta, entonces, era clara: al pueblo le interesa mucho mas conocer cómo y por que se produce la miseria; le interesa conocer quienes la ocasionan; cómo y de que manera se los puede combatir; al pueblo le interesa conocer las caras y los nombres de los esbirros, asesinos y explotadores; le interesa conocer los sistemas de explotación y sus entretelones, la verdadera historia y la verdad que sistemáticamente le fue negada; al pueblo, finalmente, le interesa conocer las causas y no los efectos. Así se comenzó a repensar ese tipo de cine, y con el nuevo planteamiento basado en la idea fundamental del interés del pueblo se orientaron los pasos futuros y se realizaron filmes que contenían y cumplían esos postulados, y que pasaron de esta manera a la ofensiva. Se los ofreció como armas de lucha contra la clase dominante y el imperialismo yanqui, puesto que se reconocía en el país a este enemigo bicéfalo. Porque era claro el nefasto papel del imperialismo y también el jugado por la clase dominante, la burguesía entreguista. Esta clase es la que permite la enajenación nacional, la que sirve de instrumento al invasor.

Por lo tanto, era importante divulgar también el mecanismo que convierte al ejercito nacional en ejercito extranjero capaz de masacrar al propio pueblo sirviendo a los intereses del invasor. Se plantearon una serie de tareas que Podían clarificar hechos históricos y contribuir a anular el manto de desinformación que se tendía sobre ellos para impedir la toma de conciencia. Por lo tanto contribuir al conocimiento liberador y a la formación de una conciencia era la tarea mas 
importante y la labor del grupo se encaminó cada vez mas decididamente en esa dirección.

La primera película del grupo Ukamau ya alarmo al gobierno, que no vaciló, posteriormente, en expulsar aparatosamente al grupo del Instituto Cinematográfico donde funcionaba y en clausurar este organismo.

Sin embargo, el gobierno militar no pudo frenar la exhibición y difusión de la película que batió todos los índices de asistencia del país. Ukamau era una película producida por un organismo del estado (el Instituto Cinematográfico) que dependía de la propia presidencia de la república; además, el estreno se hizo con asistencia de las principales autoridades, y el entonces copresidente Ovando hizo declaraciones elogiosas, innegablemente presionado por la calurosa acogida del publico asistente, que comprometió la voz oficial; y a pesar de que el ministro secretario, al tiempo que felicitaba, delante de los periodistas, a los realizadores, les decía entre dientes: Esto es una traición.

La película se exhibió simultáneamente en varias ciudades de Bolivia y estuvo en La Paz nueve semanas. Es decir, la censura y la represión -manifestadas internamente- no podían volcarse públicamente contra un producto oficial. Mas tarde se hicieron destruir las copias existentes, pero ya mas de trescientas mil personas habían visto Ukamau (los negativos de Ukamau estuvieron a punto de ser quemados en Buenos Aires en vista de que el gobierno boliviano no accedió a pagar una pequeña deuda pendiente que había dejado el extinto Instituto Cinematográfico con el laboratorio).

La expectativa, el inmenso público real y potencial que había creado Ukamau fueron factores que determinaron una respuesta mas responsable en la búsqueda que se había trazado este grupo.

Era una grave responsabilidad contar con tan masiva atención. No se podía tratar la próxima vez sino de lo fundamental, no se podía perder esa hora y media de entrega incondicional que ofrecía el pueblo al incipiente cine nacional, en temas que no se refirieran a lo mas urgente que había por denunciar y explicar; la penetración imperialista.

Entre las numerosas acciones que el imperialismo norteamericano había desatado contra Bolivia en esos años de cínico entreguismo, la campaña criminal de 
esterilización de mujeres campesinas (sin su consentimiento) constituía la mas alarmante. Esto no solamente porque en Bolivia la mortalidad infantil alcanza al $40 \%$ de promedio -lo que significa que existen zonas con el $90 \%$, en un país que, naturalmente, no aumenta demográficamente- sino porque los métodos empleados revelaban el carácter fascista del imperialismo yanqui. Por otra parte, esa acción contenía en si toda una suerte de posibilidades alegóricas que podrían permitir una visión mas amplia de lo que significa la labor depredadora del capitalismo que corrompe lo que explota, que busca la destrucción de los pueblos física y culturalmente. Por lo tanto, la denuncia no bastaba si no estaba apoyada en una explicación del contexto social existente, de la ubicación de clases y sus contradicciones. Era también la oportunidad de representar concreta y físicamente al imperialismo, que para nuestro pueblo no pasaba de ser una abstracción inaprensible. La historia de Yawar Mallku, inspirada en hechos reales, fue trabajada considerando esos aspectos y siguiendo fielmente los postulados teóricos del cine ofensivo, combatiente. Los resultados fueron alentadores. Como resultado inmediato a la difusión de Yawar Mallku se puede anotar que los norteamericanos suspendieron totalmente la distribución masiva de anticonceptivos, sacaron del país a todos los miembros de su organización que habían trabajado en los tres centros de esterilización que funcionaban en Bolivia y afrontaron la renuncia interna de otros componentes, sin animarse a desmentir la acusación que se proyectó contra ellos inclusive desde periódicos conservadores. Mas tarde se pudo conocer el caso de una población campesina que estuvo a punto de linchar a tres norteamericanos del Cuerpo de Paz, acusándolos de esterilizadores. Por vía indirecta, el film actuó sobre otras zonas: dos comunidades campesinas del Altiplano impidieron el acceso de los Cuerpos de Paz, alegando que conocían sus practicas por las denuncias del film difundidas por la radio. En 1971, ante la evidencia de documentos sobre las diversas actividades antinacionales y la presión creciente, el gobierno boliviano expulsa al Cuerpo de $\mathrm{Paz}^{6}$.

\footnotetext{
${ }^{6}$ A expulsão do "Cuerpo de Paz" aconteceu durante o Governo Popular do general Juan José Torres.
} 
Era pues la praxis la que confirmaba que un cine revolucionario podía ser un arma. Indudablemente la situación y las condiciones objetivas y subjetivas de Bolivia eran particulares y permitieron que una obra comprometida movilizara la opinión pública, utilizando para ello los mismos canales de difusión que son habitualmente empleados por las clases dominantes con carácter exclusivo en otros países. Pero tampoco puede desconocerse que para que esto fuera posible, era necesario que el grupo se propusiera producir un cine de interés y atracción populares. Es decir un cine que basara su objetivo de contribuir a crear conciencia en la comunicabilidad con el pueblo.

Se trataba de profundizar una realidad y la claridad del lenguaje no podía provenir de la simplificación sino de la lucidez con que se sintetizara la realidad. Sin embargo, a pesar de que Yawar Mallku había logrado una audiencia gigantesca, a pesar de los resultados extraordinarios con relación a los objetivos trazados para el film, se puede decir que no había logrado aun, plenamente, una comunicabilidad de activa participación. Su estructura argumentada, propia del cine de ficción situaba a la denuncia en un peligroso grado de inverosimilitud. Era necesario superar esta limitación y llegar a un cine popular que abordara los hechos reales con elementos.

Si era indispensable trabajar con la realidad y la verdad manipulando la historia viva, cotidiana era indispensable por eso mismo encontrar formas capaces de no desvirtuar ni traicionar ideológicamente los contenidos como ocurría con Yawar Mallku, que tratando sobre hechos históricos se valía de formas propias del cine de ficción sin poder probar documentalmente, por su limitación formal, su propia verdad. Los experiencias posteriores resaltaron la conciencia sobre estos problemas: Los Caminos de la Muerte y El Coraje del Pueblo constituyen los dos intentos del grupo por llegar al cine revolucionario y documental. 


\section{Por un cine imperfecto}

Julio García Espinosa (1969)

Hoy en día un cine perfecto — técnica y artísticamente logrado - es casi siempre un cine reaccionario.

La mayor tentación que se le ofrece al cine cubano en estos momentos cuando logra su objetivo de un cine de calidad, de un cine con significación cultural dentro del proceso revolucionario- es precisamente la de convertirse en un cine perfecto.

El boom del cine latinoamericano - con Brasil y Cuba a la cabeza, según los aplausos y el visto bueno de la intelectualidad europea - es similar en la actualidad al que venía monodisfrutando la novelística latinoamericana.

¿Por qué nos preocupa que nos aplaudan? ¿No está, entre las reglas del juego artístico, la finalidad de un reconocimiento público? ¿No equivale el reconocimiento europeo - a nivel de la cultura artística - a un reconocimiento mundial? ¿Que las obras realizadas en el subdesarrollo obtengan un reconocimiento de tal naturaleza no beneficia al arte y a nuestros pueblos?

Curiosamente la motivación de estas inquietudes, es necesario aclararlo, no es sólo de orden ético. Es más bien, y sobre todo, estético, si es que se puede trazar una línea tan arbitrariamente divisoria entre ambos términos.

Cuando nos preguntamos por qué somos nosotros directores de cine y no los otros, es decir, los espectadores, la pregunta no la motiva solamente una preocupación de orden ético. Sabemos que somos directores de cine porque hemos pertenecido a una minoría que ha tenido el tiempo y las circunstancias necesarias para desarrollar, en ella misma, una cultura artística; y porque los recursos materiales de la técnica cinematográfica son limitados $\mathrm{y}$, por lo tanto, al alcance de unos cuantos y no de todos. Pero ¿qué sucede si el futuro es la universalización de la enseñanza universitaria, si el desarrollo económico

y social reduce las horas de trabajo, si la evolución de la técnica cinematográfica (como ya hay señales evidentes) hace posible que ésta deje de ser privilegio de unos pocos, qué sucede si el desarrollo del videotape soluciona la capacidad 
inevitablemente limitada de los laboratorios, silos aparatos de televisión y su posibilidad de "proyectar" con independencia de la planta matriz, hacen innecesaria la construcción al infinito de salas cinematográficas? Sucede entonces no sólo un acto de justicia social, la posibilidad de que todos puedan hacer cine, sino un hecho de extrema importancia para la cultura artística: la posibilidad de rescatar, sin complejos, ni sentimientos de culpa de ninguna clase, el verdadero sentido de la actividad artística. Sucede entonces que podemos entender que el arte es una actividad "desinteresada" del hombre. Que el arte no es un trabajo. Que el artista no es propiamente un trabajador.

El sentimiento de que esto es así y la imposibilidad de practicarlo en consecuencia, es la agonía y, al mismo tiempo, el fariseísmo de todo el arte contemporáneo.

De hecho existen las dos tendencias. Los que pretenden realizarlo como una actividad "desinteresada" y los que pretenden justificarlo como una actividad “interesada". Unos y otros están en un callejón sin salida.

Cualquiera que realiza una actividad artística se pregunta en un momento dado qué sentido tiene lo que él hace. El simple hecho de que surja esta inquietud demuestra que existen factores que la motivan. Factores que, a su vez, evidencian que el arte no se desarrolla libremente. Los que se empecinan en negarle un sentido específico, sienten el peso moral de su egoísmo. Los que pretenden adjudicarle uno, compensan con la bondad social su mala conciencia. No importa que los mediadores (críticos, teóricos, etc.) traten de justificar unos casos y otros. El mediador es para el artista contemporáneo su aspirina, su píldora tranquilizadora. Pero como ésta, sólo quita el dolor de cabeza pasajeramente. Es cierto, sin embargo, que el arte, como diablillo caprichoso, sigue asomando esporádicamente la cabeza en no importa qué tendencia. Sin duda es más fácil definir el arte por lo que no es que por lo que es, si es que se puede hablar de definiciones cerradas no ya para el arte sino para cualquier actividad de la vida. El espíritu de contradicción lo impregna todo y ya nada ni nadie se dejan encerrar en un marco por muy dorado que éste sea.

Es posible que el arte nos dé una visión de la sociedad o de la naturaleza humana y que, al mismo tiempo, no se pueda definir como visión de la sociedad o de la naturaleza 
humana. Es posible que en el placer estético esté implícito un cierto narcisismo de la conciencia en reconocerse pequeña conciencia histórica, sociológica, sicológica, filosófica, etc., y al mismo tiempo no basta esta sensación para explicar el placer estético.

¿No es mucho más cercano a la naturaleza artística concebirla con su propio poder cognoscitivo? ¿Es decir que el arte no es "ilustración” de ideas que pueden ser dichas por la filosofía, la sociología, la sicología? El deseo de todo artista de expresar lo inexpresable no es más que el deseo de expresar la visión del tema en términos inexpresables por otras vías que no sean las artísticas. Tal vez su poder cognoscitivo es como el del juego para el niño. Tal vez el placer estético es el placer que nos provoca sentir la funcionalidad ( $\sin$ un fin específico) de nuestra inteligencia y nuestra propia sensibilidad. El arte puede estimular, en general, la función creadora del hombre. Puede operar una actitud de cambio frente a la vida. Pero, a diferencia de la ciencia, nos enriquece en forma tal que sus resultados no son específicos, no se pueden aplicar a algo en particular. De ahí que lo podamos llamar una actividad "desinteresada", que podamos decir que el arte no es propiamente un "trabajo", que el artista es tal vez el menos intelectual de los intelectuales.

¿Por qué el artista, sin embargo, siente la necesidad de justificarse como "trabajador", como "intelectual", como "profesional", como hombre disciplinado y organizado, a la par de cualquier otra tarea productiva? ¿Por qué siente la necesidad de hipertrofiar la importancia de su actividad? ¿Por qué siente la necesidad de tener críticos — mediadores — que lo defiendan, lo justifiquen, lo interpreten? ¿Por qué habla orgullosamente de "mis críticos”? ¿Por qué Siente la necesidad de hacer declaraciones trascendentes, como si él fuera el verdadero intérprete de la sociedad y del ser humano? ¿Por qué pretende considerarse crítico y conciencia de la sociedad cuando - si bien estos objetivos pueden estar implícitos o aun explícitos en determinadas circunstancias - en un verdadero proceso revolucionario esas funciones las debemos ejercer todos, es decir, el pueblo? ¿Y por qué entonces, por otra parte, se ve en la necesidad de limitar estos objetivos, estas actitudes, estas características? ¿Por qué, al mismo tiempo, plantea estas limitaciones necesarias para que la obra no se convierta en un panfleto o en un ensayo sociológico? ¿Por qué semejante fariseísmo? ¿Por qué protegerse y ganar importancia como trabajador, 
político y científico (revolucionarios, se entienden) y no estar dispuestos a correr los riesgos de éstos?

El problema es complejo. No se trata fundamentalmente de oportunismo y ni siquiera de cobardía. Un verdadero artista está dispuesto a correr todos los riesgos si tiene la certeza de que su obra no dejará de ser una expresión artística. El único riesgo que él no acepta es el de que la obra no tenga una calidad artística.

También están los que aceptan y defienden la función "desinteresada" del arte. Pretenden ser más consecuentes. Prefieren la amargura de un mundo cerrado en la esperanza de que mañana la historia les hará justicia. Pero es el caso que todavía hoy la Gioconda no la pueden disfrutar todos. Debían de tener menos contradicciones, debían de estar menos alienados. Pero de hecho no es así, aunque tal actitud les dé la posibilidad de una coartada más productiva en el orden personal. En general sienten la esterilidad de su "pureza" o se dedican a librar combates corrosivos pero siempre a la defensiva. Pueden incluso rechazar, en una operación a la inversa, el interés de encontrar en la obra de arte la tranquilidad, la armonía, una cierta comprensión, expresando el desequilibrio, el caos, la incertidumbre, lo cual no deja de ser también un objetivo "interesado".

¿Qué es, entonces, lo que hace imposible practicar el arte como actividad “desinteresada”? ¿Por qué esta situación es hoy más sensible que nunca? Desde que el mundo es mundo, es decir desde que el mundo es mundo dividido en clases, esta situación ha estado latente. Si hoy se ha agudizado es precisamente porque hoy empieza a existir la posibilidad de superarla. No por una toma de conciencia, no por la voluntad expresa de ningún artista, sino porque la propia realidad ha comenzado a revelar síntomas (nada utópicos) de que "en el futuro ya no habrá pintores sino, cuando mucho, hombres, que, entre otras cosas, practiquen la pintura” (Marx).

No puede haber arte "desinteresado", no puede haber un nuevo y verdadero salto cualitativo en el arte si no se termina, al mismo tiempo y para siempre, con el concepto y la realidad "elitaria" en el arte. Tres factores pueden favorecer nuestro optimismo: el desarrollo de la ciencia, la presencia social de las masas, la potencialidad revolucionaria en el mundo contemporáneo. Los tres $\sin$ orden jerárquico, los tres interrelacionados. 
¿Por qué se teme a la ciencia? ¿Por qué se teme que el arte pueda ser aplastado ante la productividad y utilidad evidentes de la ciencia? ¿Por qué ese complejo de inferioridad? Es cierto que leemos hoy con mucho más placer un buen ensayo que una novela. ¿Por qué repetimos entonces, con horror, que el mundo se vuelve más interesado, más utilitario, más materialista? ¿No es realmente maravilloso que el desarrollo de la ciencia, de la sociología, de la antropología, de la sicología, contribuya

a "depurar" el arte? La aparición, gracias a la ciencia, de medios expresivos como la fotografía y el cine (lo cual no implica invadirlos artísticamente) ¿no hizo posible una mayor "depuración” en la pintura y en el teatro? ¿Hoy la ciencia no vuelve anacrónico tanto análisis "artístico” sobre el alma humana? ¿No nos permite la ciencia librarnos hoy de tantos filmes llenos de charlatanerías y encubiertos con eso que se ha dado en llamar mundo poético? Con el avance de la ciencia el arte no tiene nada que perder, al contrario, tiene todo un mundo que ganar. ¿Cuál es el temor entonces? La ciencia desnuda al arte y parece que no es fácil andar sin ropa por la calle.

La verdadera tragedia del artista contemporáneo está en la imposibilidad de ejercer el arte como actividad minoritaria. Se dice que el arte no puede seducir sin la cooperación del sujeto que hace la experiencia. Es cierto. ¿Pero qué hacer para que el público deje de ser objeto y se convierta en sujeto?

El desarrollo de la ciencia, de la técnica, de las teorías y prácticas más avanzadas, han hecho posible, como nunca, la presencia activa de las masas en la vida social. En el plano de la vida artística hay más espectadores que en ningún otro momento de la historia. Es la primera fase de un proceso "deselitario". De lo que se trata ahora es de saber si empiezan a existir las condiciones para que esos espectadores se conviertan en autores. Es decir, no en espectadores más activos, en coautores, sino en verdaderos autores. De lo que se trata es de preguntarse si el arte es realmente una actividad de especialistas. Si el arte, por designios extrahumanos, es posibilidad de unos cuantos o posibilidad de todos.

¿Cómo confiar las perspectivas y posibilidades del arte a la simple educación del pueblo, en tanto que espectadores? ¿El gusto definido por la "alta cultura", una vez sobrepasado por ella misma, no pasa al resto de la sociedad como residuo que 
devoran y rumian los no invitados al festín? ¿No ha sido ésta una eterna espiral convertida hoy, además, en círculo vicioso? El camp y su óptica (entre otras) sobre lo viejo, es un intento de rescatar estos residuos y acortar la distancia con el pueblo. Pero la diferencia es que el camp lo rescata como valor estético, mientras que para el pueblo siguen siendo todavía valores éticos.

Nos preguntamos si es irremediable para un presente y un futuro realmente revolucionarios tener "sus" artistas, "sus" intelectuales, como la burguesía tuvo los "suyos". ¿Lo verdaderamente revolucionario no es intentar, desde ahora, contribuir a la superación de estos conceptos y prácticas minoritarias, más que en perseguir in aeternum la "calidad artística" de la obra? La actual perspectiva de la cultura artística no es más la posibilidad de que todos tengan el gusto de unos cuantos, sino la de que todos puedan ser creadores de una cultura artística. El arte siempre ha sido una necesidad de todos. Lo que no ha sido una posibilidad de todos en condiciones de igualdad. Simultáneamente al arte culto ha venido existiendo el arte popular.

El arte popular no tiene nada que ver con el llamado arte de masas. El arte popular necesita, y por lo tanto tiende a desarrollar, el gusto personal, individual, del pueblo. El arte de masas o para las masas, por el contrario, necesita que el pueblo no tenga gusto. El arte de masas será en realidad tal, cuando verdaderamente lo hagan las masas. Arte de masas, hoy en día, es el arte que hacen unos pocos para las masas. Grotowski dice que el teatro de hoy debe ser de minorías porque es el cine quien puede hacer un arte de masas. No es cierto. Posiblemente no exista un arte más minoritario hoy que el cine. El cine hoy, en todas partes, lo hace una minoría para las masas. Posiblemente sea el cine el arte que demore más en llegar al poder de las masas. Arte de masas, es pues, el arte popular, el que hacen las masas. Arte para las masas es, como bien dice Hauser, la producción desarrollada de una masa reducida al único papel de espectadora y consumidora.

El arte popular es el que ha hecho siempre la parte más inculta de la sociedad. Pero este sector inculto ha logrado conservar para el arte características profundamente cultas. Una de ellas es que los creadores son al mismo tiempo los espectadores y viceversa. No existe, entre quienes lo producen y lo reciben, una línea tan marcadamente definida. El arte culto, en nuestros días, ha logrado también esa situación. La gran cuota de libertad del arte moderno no es más que la conquista de un 
nuevo interlocutor: el propio artista. Por eso es inútil esforzarse en luchar para que sustituya a la burguesía por las masas como nuevo y potencial espectador. Esta situación mantenida por el arte popular, conquistada por el arte culto, debe fundirse y convertirse en patrimonio de todos. Ese y no otro debe ser el gran objetivo de una cultura artística auténticamente revolucionaria.

Pero el arte popular conserva otra característica aún más importante para la cultura. El arte popular se realiza como una actividad más de la vida. El arte culto al revés. El arte culto se desarrolla como actividad única, específica, es decir, se desarrolla no como actividad sino como realización de tipo personal. He ahí el precio cruel de haber tenido que mantener la existencia de la actividad artística a costa de la inexistencia de ella en el

pueblo. ¿Pretender realizarse al margen de la vida no ha sido una coartada demasiado dolorosa para el artista y para el propio arte? ¿Pretender el arte como secta, como sociedad dentro de la sociedad, como tierra prometida donde podamos realizarnos fugazmente, por un momento, por unos instantes, no es crearnos la ilusión de que realizándonos en el plano de la conciencia nos realizamos también en el de la existencia? ¿No resulta todo esto demasiado obvio en las actuales circunstancias? La lección esencial del arte popular es que éste es realizado como una actividad dentro de la vida, que el hombre no debe realizarse como artista sino plenamente, que el artista no debe realizarse como artista sino como hombre.

En el mundo moderno, principalmente en los países capitalistas desarrollados y en los países en proceso revolucionario, hay síntomas alarmantes, señales evidentes que presagian un cambio. Diríamos que empieza a surgir la posibilidad de superar esta tradicional disociación. No son síntomas provocados por la conciencia, sino por la propia realidad. Gran parte de la batalla del arte moderno es, de hecho, para “democratizar" el arte. ¿Qué otra cosa significa combatir las limitaciones del gusto, el arte para museos, las líneas marcadamente divisorias entre creador y público? ¿Qué es hoy la belleza? ¿Dónde se encuentra? ¿En las etiquetas de las sopas Campbell, en la tapa de un latón de basura, en los "muñequitos"? ¿Se pretende hoy hasta cuestionar el valor de eternidad en la obra de arte? ¿Qué significan esas esculturas aparecidas en recientes exposiciones, hechas de bloques de hielo y que, por consecuencia, se derriten mientras el público las observa? ¿No es —más que la 
desaparición del arte - la pretensión de que desaparezca el espectador? ¿Y el valor de la obra como valor irreproducible? ¿Tienen menos valor las reproducciones de nuestros hermosos afiches que el original? ¿Y qué decir de las infinitas copias de un filme? ¿No existe un afán por saltar la barrera del arte "elitario" en esos pintores que confían a cualquiera, no ya a sus discípulos, parte de la realización de la obra? ¿No existe igual actitud en los compositores cuyas obras permiten amplia libertad a los ejecutantes? ¿No hay toda una tendencia en el arte moderno de hacer participar cada vez más al espectador? ¿No es éste o no debe ser éste, al menos, el desenlace lógico? ¿No es ésta una tendencia colectivista e individualista al mismo tiempo? ¿Si se plantea la posibilidad de participación de todos, no se está aceptando la posibilidad de creación individual que tenemos todos? ¿Cuando Grotowski habla de que el teatro de hoy debe ser de minorías, no se equivoca? ¿No es justamente lo contrario? ¿Teatro de la pobreza no quiere decir

cii realidad teatro del más alto refinamiento? Teatro que no necesita ningún valor secundario, es decir, que no necesita vestuario, escenografía, maquillaje, incluso escenario. ¿No quiere decir esto que las condiciones materiales se han reducido al máximo y que, desde ese punto de vista, la posibilidad de hacer teatro está al alcance de todos? ¿Y el hecho de que el teatro tenga cada vez menos público no quiere decir que las condiciones empiezan a estar maduras para que se convierta en un verdadero teatro de masas? Tal vez la tragedia del teatro sea que ha llegado demasiado temprano a ese punto de su evolución.

Cuando miramos hacia Europa nos frotamos las manos. Vemos a la vieja cultura imposibilitada hoy de darle una respuesta a los problemas del arte. En realidad sucede que Europa no puede ya responder en forma tradicional y, al mismo tiempo, le es muy difícil hacerlo de una manera enteramente nueva. Europa ya no es capaz de darle al mundo un nuevo "ismo" y no está en condiciones de hacerlos desaparecer para siempre. Pensamos entonces que ha llegado nuestro momento. Que al fin los subdesarrollados pueden disfrazarse de hombres "cultos". Es nuestro mayor peligro. Esa es nuestra mayor tentación. Ese es el oportunismo de unos cuantos en nuestro continente. Porque, efectivamente, dado el atraso técnico y científico, dada la poca presencia de las masas en la vida social, todavía este continente puede responder en forma tradicional, es decir, reafirmando el concepto y la práctica "elitaria” en el arte. 
Y tal vez entonces la verdadera causa del aplauso europeo a algunas de nuestras obras, literarias, fílmicas, no sea otra que la de una cierta nostalgia que le provocamos. Después de todo el europeo no tiene otra Europa a quien volver los ojos. Sin embargo, el tercer factor, el más im-portante de todos, la revolución, está presente en nosotros como en ninguna otra parte. Y ella sí es nuestra verdadera oportunidad. Es la revolución lo que hace posible otra alternativa, lo que puede ofrecer una respuesta auténticamente nueva, lo que nos permite barrer de una vez y para siempre con los conceptos y prácticas minoritarias en el arte. Porque es la revolución y el proceso revolucionario lo único que puede hacer posible la presencia total y libre de las masas. Porque esta presencia de las masas será la desaparición definitiva de la estrecha división del trabajo, de la sociedad dividida en clases y sectores. Por eso para nosotros la revolución es la expresión más alta de la cultura, porque hará desaparecer la cultura artística como cultura fragmentaria del hombre.

Para ese futuro cierto, para esa perspectiva incuestionable, las respuestas en el presente pueden ser tantas como países hay en nuestro continente. Cada parte, cada manifestación artística, deberá hallar la suya propia, puesto que las características y los niveles alcanzados no son iguales.

¿Cuál puede ser la del cine cubano en particular?

Paradójicamente pensamos que será una nueva poética y no una nueva política cultural. Poética cuya verdadera finalidad será, sin embargo, suicidarse, desaparecer como tal. La realidad, al mismo tiempo, es que todavía existirán entre nosotros otras concepciones artísticas (que entendemos, además, productivas para la cultura) como existen la pequeña propiedad campesina y la religión. Pero es cierto que en materia de política cultural se nos plantea un problema serio: la escuela de cine. ¿Es justo seguir desarrollando especialistas de cine? Por el momento parece inevitable. ¿Y cuál será nuestra eterna y fundamental cantera? ¿Los alumnos de la Escuela de Artes y Letras de la Universidad? ¿Y no tenemos que plantearnos desde ahora si dicha Escuela deberá tener una vida limitada? ¿Qué perseguimos con la Escuela de Artes y Letras? ¿Futuros artistas en potencia? ¿Futuro público especializado? ¿No tenemos que irnos pregun-tando si desde ahora podemos hacer algo para ir acabando con esa división entre cultura artística y cultura científica? ¿Cuál es el verdadero prestigio de la cultura artística? ¿De dónde le viene ese prestigio que, inclusive, le ha hecho 
posible acaparar para sí el concepto total de cultura? ¿No está basado, acaso, en el enorme prestigio que ha gozado siempre el espíritu por encima del cuerpo? ¿No se ha visto siempre a la cultura artística como parte espiritual de la sociedad y a la científica como su cuerpo? ¿El rechazo tradicional al cuerpo, a la vida material, a los problemas concretos de la vida material, no se deben también a que tenemos el concepto de que las cosas del espíritu son más elevadas, más elegantes, más serias, más profundas? ¿No podemos, desde ahora, ir haciendo algo para acabar con esa artificial división? ¿No podemos ir pensando desde ahora que el cuerpo y las cosas del cuerpo son también elegantes, que la vida material también es bella? ¿No podemos entender que, en realidad, el alma está en el cuerpo, como el espíritu en la vida material, como - para hablar inclusive en términos estrictamente artísticos- el fondo en la superficie, el contenido en la forma? ¿No debemos pretender entonces que nuestros futuros alumnos $\mathrm{y}$, por lo tanto, nuestros futu-ros cineastas sean los propios economistas, agrónomos, etc? ¿Y por otra parte, simultáneamente, no debemos intentar lo mismo para los mejores trabajadores de las mejores unidades del país, los trabajadores que más se estén desarrollando

políticamente? ¿Nos parece evidente que se pueda desarrollar el gusto de las masas mientras exista la división entre las dos culturas, mientras las masas no sean las verdaderas dueñas de los medios de producción artísticos? La revolución nos ha liberado a nosotros como sector artístico. ¿No nos parece completamente lógico que seamos nosotros mismos quienes contribuyamos a liberar los medios privados de producción artística? Sobre estos problemas, naturalmente, habrá que pensar y discutir mucho todavía.

Una nueva poética para el cine será, ante todo y sobre todo, una poética "interesada", un arte "interesado", un cine conciente y resueltamente "interesado", es decir, un cine imperfecto. Un arte "desinteresado", como plena actividad estética, ya sólo podrá hacerse cuando sea el pueblo quien haga el arte. El arte hoy deberá asimilar una cuota de trabajo en interés de que el trabajo vaya asimilando una cuota de arte.

La divisa de este cine imperfecto (que no hay que inventar porque ya ha surgido) es: "No nos interesan los problemas de los neuróticos, nos interesan los problemas de los lúcidos", como diría Glauber Rocha. 
El arte no necesita más del neurótico y de sus problemas. Es el neurótico quien sigue necesitando del arte, quien lo necesita como objeto interesado, como alivio, como coartada o, como diría Freud, como sublimación de sus problemas. El neurótico puede hacer arte pero el arte no tiene porque hacer neuróticos. Tradicionalmente se ha considerado que los problemas para el arte no están en los sanos, sino en los enfermos, no están en los normales sino en los anormales, no están en los que luchan sino en los que lloran, no están en los lúcidos sino en los neuróticos. El cine imperfecto está cambiando dicha impostación. Es al enfermo y no al sano a quien más creemos, en quien más confiamos, porque su verdad la purga el sufrimiento. Sin embargo el sufrimiento y la elegancia no tienen por qué ser sinónimos. Hay todavía una corriente en el arte moderno — relacionada, sin duda, con la tradición cristianaque identifica la seriedad con el sufrimiento. El espectro de Margarita Gautier impregna todavía la actividad artística de nuestros días. Sólo el que sufre, sólo el que está enfermo, es elegante y serio y hasta bello. Sólo en él reconocemos las posibilidades de una autenticidad, de una seriedad, de una sinceridad. Es necesario que el cine imperfecto termine con esta tradición. Después de todo no sólo los niños, también los mayores, na-cieron para ser felices.

El cine imperfecto halla un nuevo destinatario en los que luchan. Y, en los problemas de éstos, encuentra su temática. Los lúcidos, para el cine imperfecto, son aquellos que piensan y sienten que viven en un mundo que pueden cambiar, que, pese a los problemas y las dificultades, están convencidos que lo pueden cambiar y revolucionariamente. El cine imperfecto no tiene, entonces, que luchar para hacer un "público". Al contrario. Puede decirse que, en estos momentos, existe más "público" para un cine de esta naturaleza que cineastas para dicho "público".

¿Qué nos exige este nuevo interlocutor? ¿Un arte cargado de ejemplos morales dignos de ser imitados? No. El hombre es más creador que imitador. Por otra parte, los ejemplos morales es él quien nos los puede dar a nosotros. Si acaso puede pedirnos una obra más plena, total, no importa si dirigida conjunta o diferencialmente a la inteligencia, a la emoción o la intuición. ¿Puede pedirnos un cine de denuncia? Sí y no. No si la denuncia está dirigida a los otros, si la denuncia está concebida para que nos compadezcan y tomen conciencia los que no luchan. Sí si la denuncia sirve como información, como testimonio, como un arma más de 
combate para los que luchan. ¿Denunciar el imperialismo para demostrar una vez más que es malo? ¿Para qué si los que luchan ya luchan principalmente conÁ tra el imperialismo? Denunciar al imperialismo pero, sobre todo, en aquellos aspectos que ofrecen la posibilidad de plantearle combates concretos. Un cine, por ejemplo, que denuncie a los que luchan los "pasos perdidos" de un esbirro que hay que ajusticiar, sería un excelente ejemplo de cine-denuncia. El cine imperfecto entendamos que exige, sobre todo, mostrar el proceso de los problemas. Es decir, lo contrario a un cine que se dedique fundamentalmente a celebrar los resultados. Lo contrario a un cine que "ilustra bellamente" las ideas o conceptos que ya poseemos. (La actitud narcista no tiene nada que ver con los que luchan.) Mostrar un proceso no es precisamente analizarlo. Analizar, en el sentido tradicional de la palabra, implica siempre un juicio previo, cerrado. Analizar un problema es mostrar el problema (no su proceso) impregnado de juicios que genera a priori el propio análisis. Analizar es bloquear de antemano las posibilidades de análisis del interlocutor. Mostrar el proceso de un problema es someterlo a juicio sin emitir el fallo. Hay un tipo de periodismo que consiste en dar el comentario más que la noticia. Hay otro tipo de periodismo que consiste en dar las noticias pero valorizándolas mediante el montaje o compaginación del periódico. Mostrar el proceso de un problema es como mostrar el desarrollo propio de la noticia; sin el comentario, es como mostrar el desarrollo pluralista $-\sin$

valorizarlo- de una información. Lo subjetivo es la selección del problema condicionada por el interés del destinatario, que es el sujeto. Lo objetivo sería mostrar el proceso, que es el objeto.

El cine imperfecto es una respuesta. Pero también es una pregunta que irá encontrando sus respuestas en el propio desarrollo. El cine imperfecto puede utilizar el documental o la ficción, o ambos. Puede utilizar un género u otro, o todos. Puede utilizar el cine como arte pluralista o como expresión específica. Le es igual. No son éstas sus alternativas ni sus problemas, ni mucho menos sus objetivos. No son éstas las batallas ni las polémicas que le interesa librar.

El cine imperfecto puede ser también divertido. Divertido para el cineasta y para su nuevo interlocutor. Los que luchan no luchan al margen de la vida sino dentro. La lucha es vida y viceversa. No se lucha para "después" vivir. La lucha exige una 
organización que es la organización de la vida. Aun en la fase más extrema como es la guerra total y directa, la vida se organiza, lo cual es organizar la lucha. Y en la vida, como en la lucha, hay de todo, incluso la diversión. El cine imperfecto puede divertirse, precisamente, con todo lo que lo niega.

El cine imperfecto no es exhibicionista en el doble sentido literal de la palabra. No lo es en el sentido narcisista; ni lo es en el sentido mercantilista, es decir, en el marcado interés de exhibirse en salas y circuitos establecidos. Hay que recordar que la muerte artística del vedetismo en los actores resultó positiva para el arte. No hay por qué dudar que la desaparición del vedetismo en los directores pueda ofrecer perspectivas similares. Justamente el cine imperfecto debe trabajar, desde ahora, conjuntamente, con sociólogos, dirigentes revolucionarios, sicólogos, economistas, etc. Por otra parte el cine imperfecto rechaza los servicios de la crítica. Considera anacrónica la función de mediadores e intermediarios.

Al cine imperfecto no le interesa más la calidad ni la técnica. El cine imperfecto lo mismo se puede hacer con una Mitchell que con una cámara de $8 \mathrm{~mm}$. Lo mismo se puede hacer en estudio que con una guerrilla en medio de la selva. Al cine imperfecto no le interesa más un gusto determinado y mucho menos el "buen gusto". de la obra de un artista no le interesa encontrar más la calidad. Lo único que le interesa de un artista es saber cómo responder a la siguiente pregunta: ¿Qué hace para saltar la barrera de un interlocutor "culto" y minoritario que hasta ahora condiciona la calidad de su obra?

El cineasta de esta nueva poética no debe ver en ella el objeto de una realización personal. Debe tener, también desde ahora, otra actividad. Debe jerarquizar su condición o su aspiración de revolucionario por encima de todo. Debe tratar de realizarse, en una palabra, como hombre y no sólo como artista. El cine imperfecto no puede olvidar que su objetivo esencial es el de desaparecer como una nueva poética. No se trata más de sustituir una escuela por otra, un ismo por otro, una poesía por una antipoesía, sino de que, efectivamente, lleguen a surgir mil flores distintas. El futuro es del folklore. No exhibamos más el folklore con orgullo demagógico, con un carácter ce-lebrativo, exhibámoslo más bien como una denuncia cruel, como un testimonio doloroso del nivel en que los pueblos fueron obligados a detener su poder de creación artística. El futuro será, sin duda, del folklore. Pero, 
entonces, ya no habrá necesidad de llamarlo así porque nada ni nadie podrá volver a paralizar el espíritu creador del pueblo.

El arte no va a desaparecer en la nada. Va a desaparecer en el todo.

La Habana, diciembre 7 de 1969. 


\section{Dialéctica del espectador}

Tomás Gutiérrez Alea (1982)

\section{Cine "Popular" y Cine Popular}

Se acepta comúnmente que el cine es, de todas las artes, la más popular. Sin embargo, no siempre fue así. Durante mucho tiempo subsistió la confusión en torno al cine en lo que se refiere a su condición de arte. La confusión aún subsiste en torno a su carácter popular.

Todavía hoy puede decirse que el cine está marcado por su origen de clase. A pesar de que a través de su corta historia ha tenido momentos de rebeldía, de búsquedas y de auténticos logros como expresión de las tendencias más revolucionarias, el cine sigue siendo en gran medida la encarnación más natural del espíritu pequeño-burgués que lo animó en su nacimiento hace apenas ocho décadas.

El capitalismo iniciaba su fase imperialista. El modesto invento de un aparato que permitía captar y reproducir imágenes de la realidad en movimiento no fue otra cosa, en un principio, que un ingenioso juguete de feria por medio del cual el espectador podía sentirse trasladado a los lugares más recónditos del mundo sin moverse de su lugar. Muy pronto salió de la feria, lo cual no quiere decir que haya alcanzado un estatus más digno y respetable: se fue desarrollando como una verdadera industria del espectáculo y comenzó a producir en serie una mercancía apta para satisfacer los gustos y alentar las aspiraciones de una sociedad dominada por una burguesía que extendía su poder a todos los rincones del mundo. Desde el primer momento se abrió a dos caminos paralelos: fue documento "veras" de algunos aspectos de la realidad y fue por otro lado fascinación de mago. Entre esos dos polos - el documento y la ficción - se ha movido siempre el cine. Muy pronto se hizo “popular”, no en el sentido de que fuera expresión d el pueblo, de los sectores más 1 oprimidos y más explotados por un sistema de producción enajenante, sino porque logró atraer a un público indiferenciado, mayoritario, ávido de ilusiones.

El cine no puede dejar de asumir — más radicalmente quizás que cualquier otro medio de expresión artística— su condición de mercancía. El éxito comercial 
que obtiene lo impulsa en su desarrollo vertiginoso. Se convierte en una industria compleja y costosa y tiene que inventar toda clase de fórmulas y recetas para que el espectáculo que ofrece reciba el favor del público más vasto, de cuya masividad depende para su mera subsistencia. De ahí —más que del hecho de tratarse de un medio que aún se expresaba con un lenguaje balbuciente-, de su condición de mercancía y de su carácter "popular", es que proviene la resistencia que hubo para elevar el cine a la categoría de verdadero arte entre los círculos en que se reverenciaba incondicionalmente el arte "culto". Arte y pueblo estaban reñidos.

Hubo entonces quien pensó que el cine, para ser un arte, debía esforzarse por traducir las grandes obras de la cultura universal. Se filmaron así muchas obras engoladas y pretenciosas, pesantes y retóricas, que no tenían nada que ver con el naciente lenguaje. Aparte de esas desviaciones lo cierto es que el cine constituía una actividad humana que cumplía mejor que otras una necesidad elemental de disfrute. En la práctica dirigida fundamentalmente hacia ese objetivo fue madurando el lenguaje y se fueron descubriendo posibilidades expresivas que lo llevaron a alcanzar una valoración estética, aun sin proponérselo.

El cine norteamericano, con su sentido pragmático, fue el que más avanzó por ese camino. Fue el más vital y el más rico en hallazgos técnicos y expresivos. Desde los primeros años del siglo fue conformando los distintos géneros (comedias, oestes, filmes de gángsteres, superproducciones históricas, melodramas...) que rápidamente se convirtieron en "clásicos", es decir, se consolidaron como modelos formales y alcanzaron un alto nivel de desarrollo al mismo tiempo que se convertían en estereotipos vacíos. Fueron la expresión más eficaz de una cultura de masas en función de un consumidor pasivo, de un espectador contemplativo y desgarrado en tanto que la realidad reclama de él una acción y al mismo tiempo le cierra todas las posibilidades de actuar.

El cine, con su posibilidad de crear verdaderos fantasmas, imágenes de luces y sombras, inasibles como un sueño compartido, fue el mejor vehículo para alentar falsas ilusiones en el espectador, para servirle de refugio, de sucedáneo de una realidad que le impedía de-sarrollarse humanamente y que, a modo de compensación, le permitía soñar despierto. 
Los aparatos y los mecanismos de producción del cine fueron inventados y creados en función de los gustos y las necesidades de la burguesía. El cine se convirtió rápidamente en la más concreta manifestación de su espíritu, en la objetivación de sus sueños. Estaba bien claro para ella que el cine no es una continuación del trabajo, ni de la escuela, ni de la vida cotidiana con sus tensiones múltiples; que no es una ceremonia formal ni un discurso político y que lo primero que en él va a buscar el espectador agobiado es placer y descanso para llenar su tiempo libre. Pero lo cierto es que el grueso de la producción cinematográfica raras veces rebasaba los niveles más vulgares de comunicación con el público: lo importante era la cantidad de dinero que podía obtenerse con cualquier producto, no la calidad artística alcanzable.

Las vanguardias europeas de los años 20 también hicieron su incursión en el cine y dejaron unas pocas obras en las que exploraron todo un vasto campo de posibilidades expresivas. Fue un vano intento por rescatar al cine de la vulgaridad a que lo condenaba el comercialismo y no pudo echar raíces, aunque gracias a algunas obras excepcionales no fue un movimiento del todo estéril.

Pero no fue hasta la creación del cine soviético que, a partir de la preocupación teórica de sus maestros y los aportes prácticos que hicieron al nuevo medio, se empezó a aceptar oficialmente una evidencia: había nacido no sólo un nuevo lenguaje, sino también un nuevo arte. "Arte colectivo por excelencia, destinado a las masas", como fue calificado entonces, el cine soviético alcanzó el máximo de coherencia con el momento de radical transformación social que se estaba operando. Arte colectivo porque conjuga la experiencia de diversas individualidades y se nutre de la práctica de otras artes en función de un arte nuevo, un arte específicamente distinto, del cual se tomaba conciencia definitivamente. Destinado a las masas - y por ende, popular - porque expresaba los intereses, las aspiraciones y los valores de los grandes sectores del pueblo que en ese momento hacían avanzar la historia, ese primer momento del cine soviético dejó huellas profundas en todo el cine que vino después y todavía hoy el cine más moderno sigue bebiendo de sus fuentes y nutriéndose de sus búsquedas y hallazgos teóricos, que no han sido aún desarrollados plenamente. 
Los primeros años del cine sonoro coinciden con los de la crisis económica del 29 en el mundo capitalista. El cine se consolida como lenguaje audiovisual y se complica todo el aparato de producción, hasta el punto de que durante mucho tiempo no será posible realizar filmes al margen de la gran industria ni soslayar sus intereses. A pesar de eso, en los años treinta la propia industria norteamericana se ve motivada a producir algunos filmes con una visión crítica de la sociedad y del momento que estaban viviendo. Eran filmes que mantenían todas las convenciones del lenguaje ya establecido y depurado, pero que mostraban un auténtico realismo en el tratamiento de temas que estaban a la orden del día. Este cine que hablaba de los conflictos sociales que todos padecían surgió en una coyuntura propicia pero muy pronto derivó hacia un reformismo complaciente. Son los años del Código Hays, también conocido como "Código del Pudor", instrumento de censura y propaganda que respondía a los intereses del gran capital financiero y que señaló los estrechos cauces ideológicos por los que habría de moverse el cine norteamericano durante mucho tiempo ${ }^{7}$.

Hacia el final de la Segunda Guerra Mundial, con las heridas aún abiertas y circunstancias políticas favorables, surge el cine neorrealista italiano, que con todas sus limitaciones políticas e ideológicas fue un movimiento vivo, fecundo en la medida en que transitaba por los caminos de un cine auténticamente popular.

En Francia aparece una "nueva ola" de directores jóvenes que al calor de la posguerra se lanzaron impetuosos a revolucionar el cine pero sin superar los limites del mundo pequeño-burgués. Entre ellos, Godard se destaca como el gran destructor del cine burgués. Tomando a Brecht como punto de partida $-\mathrm{y}$ a la "nueva izquierda" como punto de llegada — pretende hacer la revolución desde la pantalla. Su ingenio, su imaginación y su agresividad desmañada lo colocan en un lugar privilegiado entre los cineastas malditos. Alcanzó a hacer un cine antiburgués, pero

\footnotetext{
${ }^{7}$ Este famoso código plantea, entre otras cosas, que el cine debe "forjar caracteres, desarrollar el verdadero ideal e inculcar rectos principios, bajo la forma de relatos atrayentes proponiendo a la admiración del espectador hermosos ejemplos de conducta". Independientemente de cualquier discrepancia con el "verdadero" ideal y con los "rectos" principios que trataba de promover este revelador documento, resulta interesante ver cómo se acoge al mecanismo más pueril —el de proponer a la admiración del espectador "hermosos ejemplos de conducta"- y sin duda el que mejor transparenta una actitud reaccionaria porque sólo intenta forjar una imagen idealizada y complaciente de la realidad.
} 
no pudo hacer un cine popular. Destacados epígonos como J. M. Straub, admirables por su ascetismo casi religioso, ya han institucionalizado esa posición y 4

algunos piensan que están haciendo la revolución en la superestructura sin necesidad de conmover la base...

Otro fenómeno que se inscribe en esas búsquedas de un cine revolucionario es el cine llamado "paralelo" o "marginal" o "alternativo", que ha surgido en los últimos años gracias al desarrollo alcanzado por la técnica y que permite la producción de un cine relativamente barato, al alcance de pequeños grupos independientes, de militantes revolucionarios. Se trata de un cine donde se expone abiertamente la ideología revolucionaria, un cine político que debe servir para movilizar a las masas y encauzarlas hacia la revolución. Como práctica revolucionaria resulta eficaz dentro de los estrechos límites en que opera. Pero no puede llegar a las grandes masas, no sólo por los obstáculos de orden político que encuentra dentro del aparato de distribución y exhibición, sino también por razones de su misma fac-tura. Las masas siguen prefiriendo los productos más acabados que les ofrece la gran industria del espectáculo.

En el mundo capitalista - y en buena parte del mundo socialista - el gran público está condicionado por determinadas convenciones de lenguaje, por fórmulas y géneros de espectáculo que son los del cine comercial burgués, de tal manera que puede decirse que el cine, como producto original de la burguesía, casi siempre ha respondido mejor a los intereses del capitalismo que a los del socialismo, a los de la burguesía que a los del proletariado, a los de una sociedad de consumo que a los de una sociedad en revolución, a la alienación que a la desalienación, a la hipocresía y a la mentira que a la verdad profunda...

El cine popular, a pesar de que cuenta con notables exponentes y con algunos fenómenos excepcionales, no siempre ha logrado conjugar plenamente la ideología revolucionaria con la masividad. Por nuestra parte, no podemos aceptar un simple criterio cuantitativo para determinar la esencia de un cine popular. Es cierto que, en última instancia, cuando hablamos de las grandes masas nos referimos al pueblo. Pero un criterio semejante es tan amplio y tan vago que resultaría imposible introducir en el mismo cualquier tipo de valoración. El número de habitantes de un país o de un sector cualquiera de un país no es más que un conjunto de personas que, 
consideradas así, en abstracto, carece de significación alguna. Si pretendemos dar con un criterio concreto de lo popular es necesario saber qué representan esas personas ubicadas no sólo en un lugar geográfico, sino en un tiempo histórico y en una clase determinada. Es necesario distinguir en ese conjunto amplio cuáles son los grupos - las grandes masas - que mejor encarnan, consciente o inconscientemente, las líneas de fuerza que configuran el desarrollo histórico, es decir, que tienden hacia el mejoramiento incesante de las condiciones de vida en el planeta. Y si el criterio para determinar lo popular toma como base esa distinción, podemos decir que su esencia radica en que sea lo mejor para esas grandes masas lo que mejor responde a sus intereses más vitales. Es cierto que en ocasiones los intereses inmediatos obnubilan los mediatos y que suele perderse de vista el objetivo final. Para precisar: lo popular debe responder no sólo al interés inmediato (que se expresa en la necesidad de disfrute, de juego, de abandono de sí mismo, de ilusión...) sino que debe responder también a la necesidad básica, al objetivo final: la transformación de la realidad y el mejoramiento del hombre. De ahí que cuando hablamos de cine popular no nos referimos al cine que simplemente es aceptado por el pueblo, sino a un cine que además exprese los intereses más profundos y más auténticos del pueblo y que responda a ellos. De acuerdo con ese criterio - y si tenemos en cuenta que en una sociedad dividida en clases el cine no puede dejar de ser un instrumento más de la clase dominante - un cine auténticamente popular sólo puede desarrollarse plenamente en una sociedad donde los intereses del pueblo coincidan con los intereses del Estado, es decir, en una sociedad socialista.

Durante la construcción del socialismo, cuando aún no ha desaparecido el proletariado como clase que ejerce el poder a través de un complejo aparato estatal, y aún subsiste la diferencia entre la ciudad y el campo, y entre el trabajo físico y el intelectual, cuando no han desaparecido del todo las relaciones mercantiles y junto a ellas algunas manifestaciones —conscientes o inconscientes - de la ideología burguesa (y lo que es peor aún: pequeño-burguesa), cuando todavía no se cuenta más que con una base material insuficiente $y$, sobre todo, mientras subsiste el imperialismo en alguna parte del mundo, la función social del arte adquiere matices muy específicos de acuerdo con los objetivos y las necesidades más urgentes, más inmediatas que se plantean los hombres cuando van sintiéndose dueños de su destino 
y trabajan por su realización ${ }^{8}$. Aquí el arte tiene como función contribuir al mejor disfrute de la vida — nivel estético—y esto lo lleva a cabo no sólo a modo de paréntesis lúdico en medio de la realidad cotidiana, sino también como un enriquecimiento de esa propia realidad; contribuir a una comprensión más profunda del mundo - nivel cognoscitivo-lo cual conlleva el desarrollo de un criterio acorde con el camino que se ha trazado la sociedad; y por último, contribuir también a reafirmar los valores de la nueva sociedad y, consecuentemente, a luchar por su conservación y desarrollo —nivel ideológico- Si bien es verdad que durante esa etapa es el nivel ideológico el que obtiene la primacía, su eficacia estará en razón directa con la eficacia del nivel estético y del nivel cognoscitivo.

Tratemos de ver cuáles pueden ser las vías más idóneas para que el cine, como manifestación específica del arte, pueda transitar hacia esos objetivos.

${ }^{8}$ En la tesis sobre cultura artística y literaria contenida en la Plataforma Programática del PCC podemos leer: "La sociedad socialista exige un arte y una literatura que, a la vez que proporcionen el disfrute estético, contribuyan a elevar el nivel cultural del pueblo. Debe lograrse el establecimiento de un clima altamente creador que impulse el progreso del arte y de la literatura como aspiración legítima de las masas trabajadoras. El arte y la literatura promoverán los más altos valores humanos, enriquecerán la vida de nuestro pueblo y participarán activamente en la formación de la personalidad comunista". 


\section{Eztétyka da Fome}

Glauber Rocha (1965)

Dispensando a introdução informativa que se transformou na característica geral das discussões sobre América Latina, prefiro situar as reações entre nossa cultura e a cultura civilizada em termos menos reduzidos do que aqueles que, também, caracterizam a análise do observador europeu. Assim, enquanto a América Latina lamenta suas misérias gerais, o interlocutor estrangeiro cultiva o sabor dessa miséria, não como sintoma trágico, mas apenas como dado formal em seu campo de interesse. Nem o latino comunica sua verdadeira miséria ao homem civilizado nem o homem civilizado compreende verdadeiramente a miséria do latino.

Eis - fundamentalmente - a situação das Artes no Brasil diante do mundo: até hoje, somente mentiras elaboradas da verdade (os exotismos formais que vulgarizam problemas sociais) conseguiram se comunicar em termos quantitativos, provocando uma série de equívocos que não terminam nos limites da Arte mas contaminam o terreno geral do político. Para o observador europeu, os processos de criação artística do mundo subsesenvolvido só o interessam na medida que satisfazem sua nostalgia do primitivismo, e este primitivismo se apresenta híbrido, disfarçado sob tardias heranças do mundo civilizado, mal compreendidas porque impostas pelo condicinamento colonialista.

A América Latina permanece colônia e o que diferencia o colonialismo de ontem do atual é apenas a forma mais aprimorada do colonizador: e além dos colonizadores de fato, as formas sutis daqueles que também sobre nós armam futuros botes. O problema internacional da $\mathrm{AL}$ é ainda um caso de mudança de colonizadores, sendo que uma libertação possível estará ainda por muito tempo em função de uma nova dependência.

Este condicionamento econômico e político nos levou ao raquitismo filosófico e à impotência, que, às vezes inconsciente, às vezes não, geram no primeiro caso, a esterilidade e no segundo a histeria. 
A esterilidade: aquelas obras encontradas fartamente em nossas artes, onde o autor se castra em exercícios formais que, todavia, não atingem a plena possessão de suas formas. O sonho frustrado da universalização: artistas que não despertaram do ideal estético adolescente. Assim, vemos centenas de quadros nas galerias, empoeirados e esquecidos; livros de contos e poemas; peças teatrais, filmes (que, sobretudo em São Paulo, provocaram inclusive falências)... O mundo oficial encarregado das artes gerou exposições carnavalescas em vários festivais e bienais, conferências fabricadas, fórmulas fáceis de sucesso, coquetéis em várias partes do mundo, além de alguns monstros oficiais da cultura, acadêmicos de Letras e Artes, júris de pintura e marchas culturais pelo país afora. Monstruosidades universitárias: as famosas revistas literárias, os concursos, os títulos.

A histeria: um capítulo mais complexo. A indignação social provoca discursos flamejantes. O primeiro sintoma é o anarquismo que marca a poesia jovem até hoje (e a pintura). O segundo é uma redução política da arte que faz má política por excesso de sectarismo. O terceiro, e mais eficaz, é a procura de uma sistematização para a arte popular. Mas o engano de tudo isso é que nosso possível equilíbrio não resulta de um corpo orgânico, mas de um titânico e autodevastador esforço de superar a impotência: e no resultado desta operação a fórceps, nós nos vemos frustrados, apenas nos limites inferiores do colonizador: e se ele nos compreende, então, não é pela lucidez de nosso diálogo mas pelo humanitarismo que nossa informação lhe inspira. Mais uma vez o paternalismo é o método de compreensão para uma linguagem de lágrimas ou de sofrimento.

A fome latina, por isto, não é somente um sintoma alarmante: é o nervo de sua própria sociedade. Aí reside a trágica originalidade do Cinema Novo diante do cinema mundial: nossa originalidade é a nossa fome e nossa maior miséria é que esta fome, sendo sentida, não é compreendida.

De Aruanda a Vidas Secas, o Cinema Novo narrou, descreveu, poetizou, discursou, analisou, excitou os temas da fome: personagens comendo terra, personagens comendo raízes, personagens roubando para comer, personagens matando para comer, personagens fugindo para comer, personagens sujas, feias, descarnadas, morando em casas sujas, feias, escuras: foi esta galeria de famintos que identificou o Cinema Novo com o miserabilismo tão condenado pelo Governo, pela 
crítica a serviço dos interesses antinacionais pelos produtores e pelo público - este último não suportando as imagens da própria miséria. Este miserabilismo do Cinema Novo opõe-se à tendência do digestivo, preconizada pelo crítico-mor da Guanabara, Carlos Lacerda: filmes de gente rica, em casas bonitas, andando em carros de luxo: filmes alegres, cômicos, rápidos, sem mensagens, de objetivos puramente industriais. Estes são os filmes que se opõem à fome, como se, na estufa e nos apartamentos de luxo, os cineastas pudessem esconder a miséria moral de uma burguesia indefinida e frágil ou se mesmo os próprios materiais técnicos e cenográficos pudessem esconder a fome que está enraizada na própria incivilização. Como se, sobretudo, neste aparato de paisagens tropicais, pudesse ser disfarçada a indigência mental dos cineastas que fazem este tipo de filme. O que fez do Cinema Novo um fenômeno de importância internacional foi justamente seu alto nível de compromisso com a verdade; foi seu próprio miserabilismo, que, antes escrito pela literatura de 30 , foi agora fotografado pelo cinema de 60; e, se antes era escrito como denúncia social, hoje passou a ser discutido como problema político. Os próprios estágios do miserabilismo em nosso cinema são internamente evolutivos. Assim, como observa Gustavo Dahl, vai desde o fenomenológico (Porta das Caixas), ao social (Vidas Secas), ao político (Deus e o Diabo), ao poético (Ganga Zumba), ao demagógico (Cinco vezes Favela), ao experimental (Sol Sobre a Lama), ao documental (Garrincha, Alegria do Povo), à comédia (Os Mendigos), experiências em vários sentidos, frustradas umas, realizadas outras, mas todas compondo, no final de três anos, um quadro histórico que, não por acaso, vai caracterizar o período Jânio-Jango: o período das grandes crises de consciência e de rebeldia, de agitação e revolução que culminou no Golpe de Abril. E foi a partir de Abril que a tese do cinema digestivo ganhou peso no Brasil, ameaçando, sistematicamente, o Cinema Novo.

Nós compreendemos esta fome que o europeu e o brasileiro na maioria não entende. Para o europeu é um estranho surrealismo tropical. Para o brasileiro é uma vergonha nacional. Ele não come, mas tem vergonha de dizer isto; e, sobretudo, não sabe de onde vem esta fome. Sabemos nós - que fizemos estes filmes feios e tristes, estes filmes gritados e desesperados onde nem sempre a razão falou mais alto - que a fome não será curada pelos planejamentos de gabinete e que os remendos do tecnicolor não escondem mas agravam seus tumores. Assim, somente uma cultura da 
fome, minando suas próprias estruturas, pode superar-se qualitativamente: a mais nobre manifestação cultural da fome é a violência. A mendicância, tradição que se implantou com a redentora piedade colonialista, tem sido uma das causadoras de mistificação política e de ufanista mentira cultural: os relatórios oficiais da fome pedem dinheiro aos países colonialistas com o fito de construir escolas sem criar professores, de construir casas sem dar trabalho, de ensinar ofício sem ensinar o analfabeto. A diplomacia pede, os economistas pedem, a política pede: o Cinema Novo, no campo internacional, nada pediu: impôs-se a violência de suas imagens e sons em vinte e dois festivais internacionais.

Pelo Cinema Novo: o comportamento exato de um faminto é a violência, e a violência de um faminto não é primitivismo. Fabiano é primitivo? Antão é primitivo? Corisco é primitivo? A mulher de Porto das Caixas é primitiva?

Do Cinema Novo: uma estética da violência antes de ser primitiva e revolucionária, eis aí o ponto inicial para que o colonizador compreenda a existência do colonizado: somente conscientizando sua possibilidade única, a violência, o colonizador pode compreender, pelo horror, a força da cultura que ele explora. Enquanto não ergue as armas o colonizado é um escravo: foi preciso um primeiro policial morto para o francês perceber um argelino.

De uma moral: essa violência, contudo, não está incorporada ao ódio, como também não diríamos que está ligada ao velho humanismo colonizador. $\mathrm{O}$ amor que esta violência encerra é tão brutal quanto a própria violência, porque não é um amor de complacência ou de contemplação mas um amor de ação e transformação.

O Cinema Novo, por isto, não fez melodramas: as mulheres do Cinema Novo sempre foram seres em busca de uma saída possível para o amor, dada a impossibilidade de amar com fome: a mulher protótipo, a de Porto das Caixas, mata o marido, a Dandara de Ganga Zumba foge de guerra para um amor romântico;Sinhá Vitória sonha com novos tempos para os filhos, Rosa vai ao crime para salvar Manuel e amá-lo em outras circunstâncias; a moça do padre precisa romper a batina para ganhar um novo homem; a mulher de O Desafio rompe com o amante porque prefere ficar fiel ao seu mundo burguês; a mulher em São Paulo S.A. quer a segurança do amor pequenoburguês e para isso tentará reduzir a vida do marido a um sistema medíocre. 
Já passou o tempo em que o Cinema Novo precisava explicar-se para existir: o Cinema Novo necessita processar-se para que se explique à medida que nossa realidade seja mais discernível à luz de pensamentos que não estejam debilitados ou delirantes pela fome.

O Cinema Novo não pode desenvolver-se efetivamente enquanto permanecer marginal ao processo econômico e cultural do continente latino-americano; além do mais, porque o Cinema Novo é um fenômeno dos povos colonizados e não uma entidade privilegiada do Brasil: onde houver um cineasta disposto a filmar a verdade e a enfrentar os padrões hipócritas e policialescos da censura, aí haverá um germe vivo do Cinema Novo. Onde houver um cineasta disposto a enfrentar o comercialismo, a exploração, a pornografia, o tecnicismo, aí haverá um germe do Cinema Novo. Onde houver um cineasta, de qualquer idade ou de qualquer procedência, pronto a pôr seu cinema e sua profissão a serviço das causas importantes de seu tempo, aí haverá um germe do Cinema Novo. A definição é esta e por esta definição o Cinema Novo se marginaliza da indústria porque o compromisso do Cinema Industrial é com a mentira e com a exploração.

A integração econômica e industrial do Cinema Novo depende da América Latina. Para esta liberdade, o Cinema Novo empenha-se, em nome de si próprio, de seus mais próximos e dispersos integrantes, dos mais burros aos mais talentosos, dos mais fracos aos mais fortes. É uma questão de moral que se refletirá nos filmes, no tempo de filmar um homem ou uma casa, no detalhe que observar, na Filosofia: não é um filme mas um conjunto de filmes em evolução que dará, por fim, ao público, a consciência de sua própria existência.

Não temos por isto maiores pontos de contato com o cinema mundial. O Cinema Novo é um projeto que se realiza na política da fome, e sofre, por isto mesmo, todas as fraquezas conseqüentes da sua existência. 



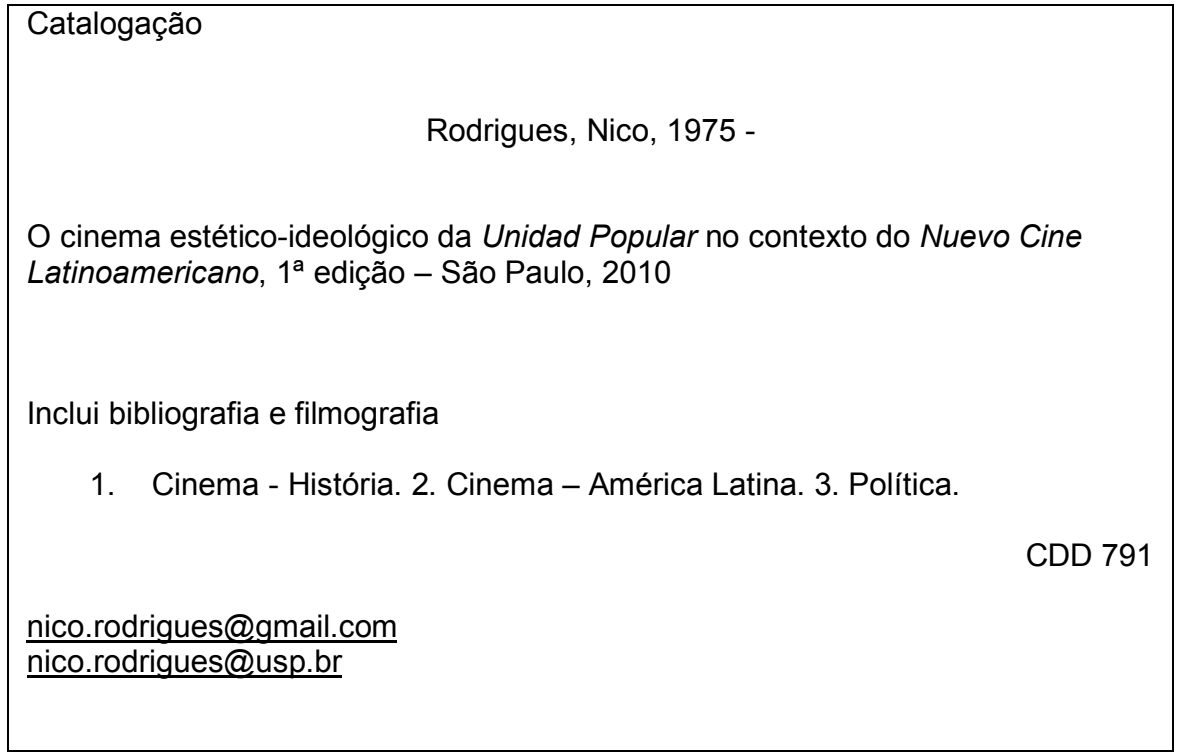

